\title{
The interplay between tectonics, sediment dynamics and gateways evolution in the Danube system from the Pannonian Basin to the western Black Sea
}

\author{
Liviu Matenco $^{\mathrm{a}, *}$, Ioan Munteanu ${ }^{\mathrm{a}, 1}$, Marten ter Borgh ${ }^{\mathrm{a}, 2}$, Adrian Stanica $^{\mathrm{b}}$, Marius Tilita ${ }^{\mathrm{a}, 1}$, Gilles Lericolais ${ }^{\mathrm{c}}$, \\ Corneliu Dinu ${ }^{\mathrm{d}}$, Gheorghe Oaie ${ }^{\mathrm{b}}$ \\ a Utrecht University, Faculty of Geosciences, Utrecht, The Netherlands \\ ${ }^{\mathrm{b}}$ National Institute of Marine Geology and Geoecology GeoEcoMar, Bucharest, Romania \\ c IFREMER, Géosciences Marines, Paris, France \\ d University of Bucharest, Faculty of Geology and Geophysics, Bucharest, Romania
}

\section{H I G H L I G H T S}

- Tectonic and sedimentological background of human-induced changes in basin systems

- Focus on the recent past evolution of the Danube River-western Black Sea system

- Source to sink analysis of basins connectivity and gateway evolution

- Tectonic vertical movements, basin evolution and key events for sediment routing

- Model of understanding basins fragmentation during continental collision

\section{A R T I C L E I N F O}

\section{Article history:}

Received 15 March 2015

Received in revised form 30 September 2015

Accepted 16 October 2015

Available online 31 October 2015

\section{Keywords:}

Source to sink

Gateways

Connectivity

Danube Basin

Black Sea

\section{GRA P H I C A L A B S T R A C T}

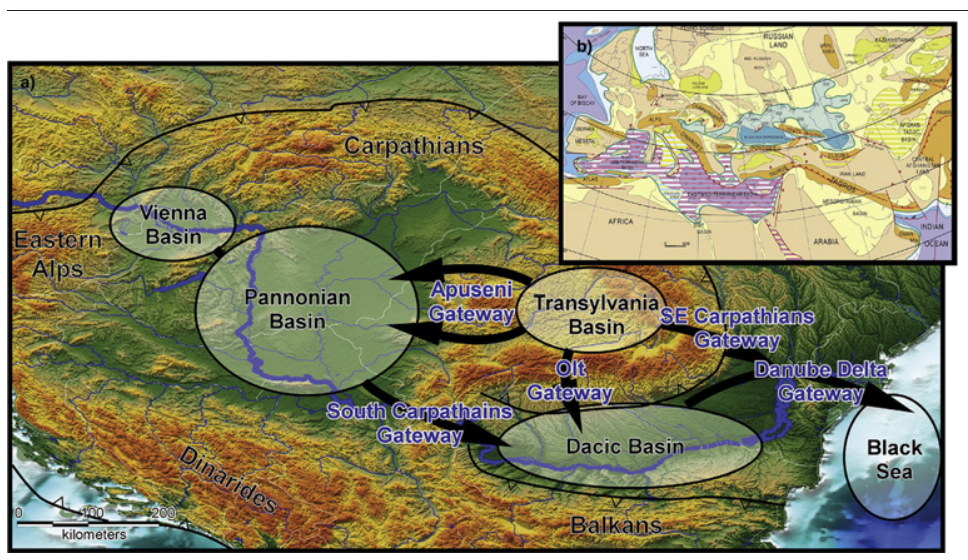

\footnotetext{
* Corresponding author at: PO Box: 80021, 3508TA Utrecht, The Netherlands.

E-mail address: liviu.matenco@uu.nl (L. Matenco).

1 Presently at Repsol Exploracion S.A., Madrid, Spain.

2 Presently at Energie Beheer Nederland (EBN) B.V., Utrecht, The Netherlands.
} 
basins and between the Dacian Basin and western Black Sea. The results demonstrate the importance of understanding threshold conditions driving rapid basins connectivity changes superposed over the longer time scale of tectonic-induced vertical movements associated with background erosion and sedimentation. The spatial and temporal scale of such processes is contrastingly different and challenging. The long-term patterns interact with recent or anthropogenic induced modifications in the natural system and may result in rapid changes at threshold conditions that can be quantified and predicted. Their understanding is critical because of frequent occurrence during orogenic evolution, as commonly observed in the Mediterranean area and discussed elsewhere. (c) 2015 Elsevier B.V. All rights reserved.

\section{Introduction}

The distribution of sediment fluxes is linked with the natural connection between source areas situated in actively uplifting mountain chains and deposition in plains, deltaic systems and, ultimately, in capturing oceans and seas. This defines an integrated source to sink system. The Danube River-western Black Sea is one of the most active European systems in terms of sediment re-distribution, posing significant societal challenges and vulnerabilities (Figs. 1 and 2, Cloetingh et al., 2005; Matenco and Andriessen, 2013). The present-day situation is related to human changes superposed over a recent geological evolution that includes not only long-term processes such as tectonic-induced vertical motions or fluvial sediment routing, but was significantly conditioned by events taking place in a specific geological situation.

Understanding source to sink systems that evolved during the last stages of mountain building requires the analysis of orogenic processes that fragmented associated sedimentary basins. These basins become gradually shallow, filled at high sedimentation rates during rapid orogenic exhumation. Such collisional fragmentation associated with major deltaic processes filling up multiple basins separated by subaerial

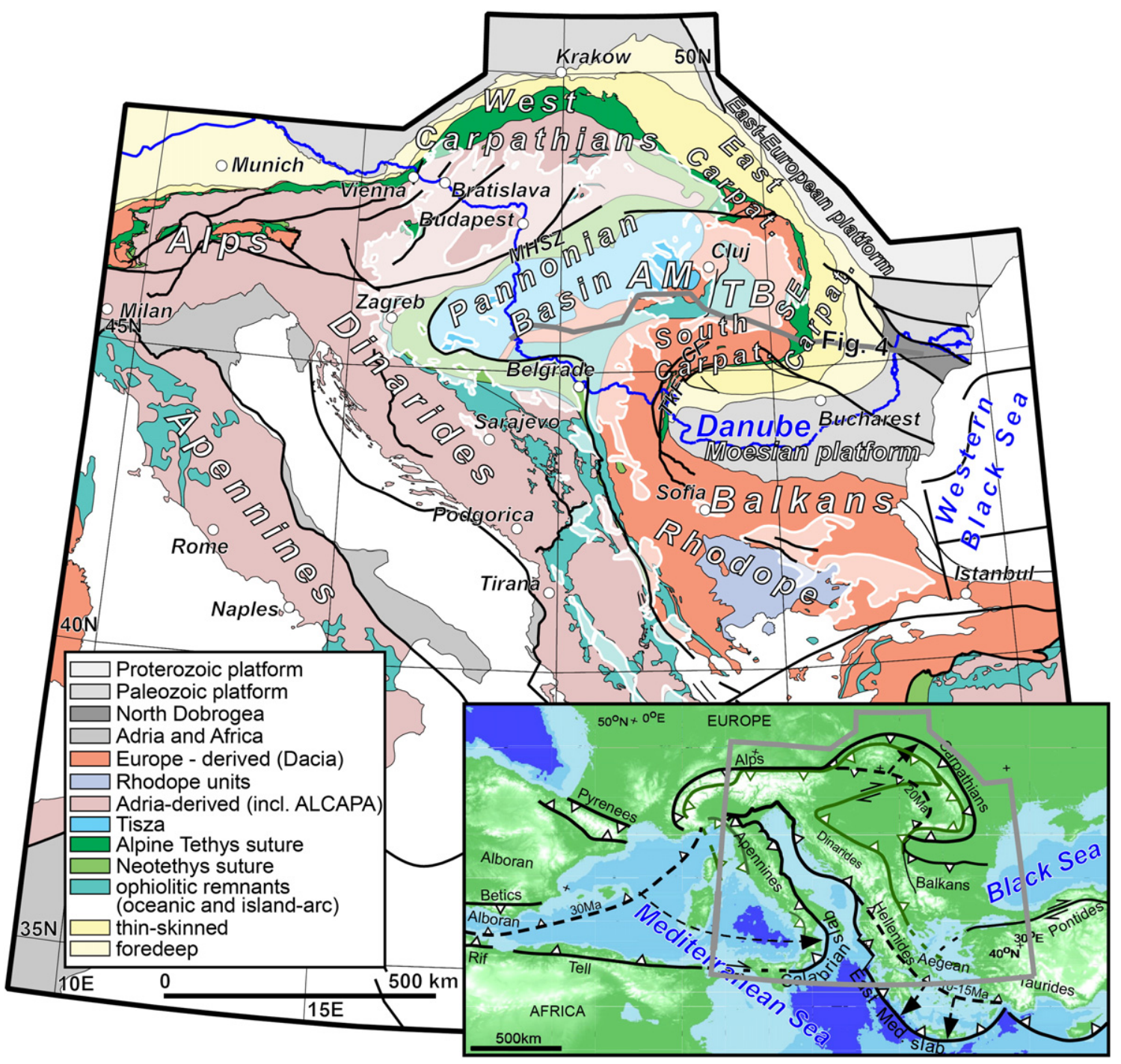

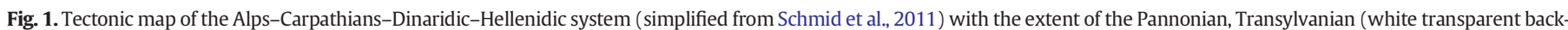

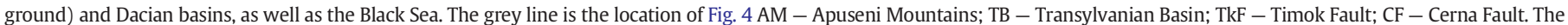

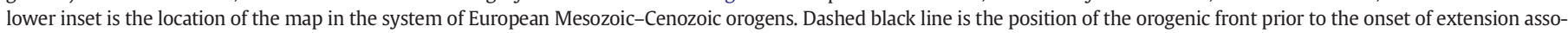
ciated with the roll-back of the Calabrian, Aegean and Carpathian slabs (modified from Wortel and Spakman, 2000). 


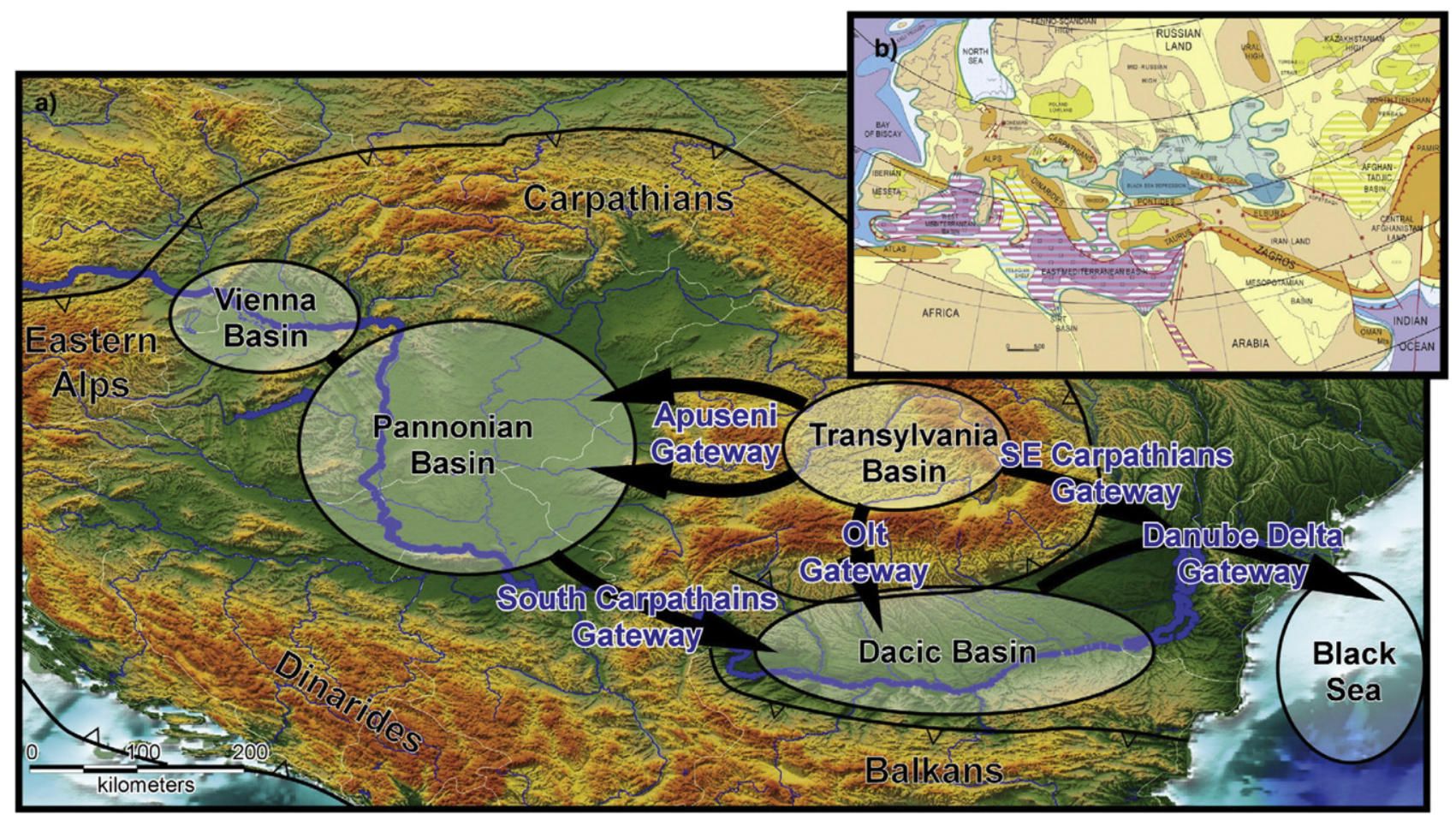

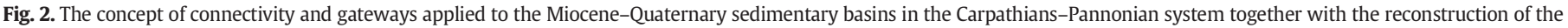
(dis)connected Paratethys basins at the time of the Messinian Salinity Crisis (after Matenco and Andriessen, 2013).

or submarine barriers are observed worldwide and make up the active geological background to human-induced changes in regions such as the Eurasian Paratethys system, the Mediterranean or the south-east Asia arc-back-arc areas (Jolivet et al., 2006; Popov et al., 2006; Pubellier and Morley, 2014).

One of the best examples of interplay between collisional mechanics and recent evolution of a source to sink system with large impact into the active evolution of landforms is the Danube Basin -western Black Sea system, in particular its eastern part that includes the Pannonian, Transylvanian and Dacian basins (Fig. 2). Major deltaic systems were active roughly along the trace of present-day Danube River and its major tributaries, causing the infill of a $\sim 1300 \mathrm{~km}$ wide area during the last 10 Ma (Jipa and Olariu, 2013; Krézsek et al., 2010; Magyar et al., 2013). At the same time, these relatively shallow water basins and surrounding mountain chains were subject to significant tectonic-driven vertical movements and associated erosion, sediment transport and deposition. These processes remain, in most situations, active at present. The coeval development of the western system of partly endemic Paratethys lakes and seas separated by the emerging CarpathoBalkans, Dinarides or Anatolia mountains, hills and submerged barriers into the present day Danube River-Black Sea system (Rögl, 1999) was marked by key events actively re-shaping sediment routing. These events often created situations of sediments trapping and starvation across barriers between basins, moments of basins connectivity (unior bi-directional) over (dis-)continuous gateways, rapid tectonic uplift and subsidence, large-scale active faulting, moments of rapid regressive basin fill and events of conditioning sediments discharge into largescale turbiditic systems (Leever et al., 2011; Matenco et al., 2010; Munteanu et al., 2012; ter Borgh et al., 2015). The mechanisms driving this inheritance are of significant importance for understanding the present-day vulnerability of the geological system (Stănică and Panin, 2009). A significant number of studies were published in recent years on the long term Miocene-Quaternary evolution $\left(10^{5}-10^{6}\right.$ My timescale) of various parts of basins and mountain ranges located in the lower Danube River and adjacent part of the Black Sea (e.g., Cloetingh et al., 2006; Matenco and Andriessen, 2013 and references therein).
This provides an optimal timing for understanding the tectonic and sedimentological background of processes operating at higher resolution $\left(10^{3}-10^{5} \mathrm{My}\right)$ and revealing the critical thresholds of the natural system impacted by human changes.

In this study we aim to analyse the tectonic and sedimentological background of the human-induced changes in the Danube Basin-Black Sea system by linking a number of key studies to understand the longterm regional evolution, the key geological events and the mechanics of the sedimentary system. This is achieved by analysing the tectonic vertical movements, evolution of relevant basins and key events affecting sediment routing and deposition. The unusual high rates of tectonic vertical movements driving the Miocene-Quaternary evolution in the Carpathians will be reviewed by looking both at the kinematics of uplifting mountain chains and at the subsidence and associated sedimentary geometry of their foreland and hinterland basins. The moments of connectivity and gateway evolution will be reviewed by analysing the connecting geometries between the Dacian Basin and the Black Sea and in between the Pannonian and Dacian basins. In particular, the onset and subsequent evolution of the massive sedimentation along the western Black Sea deep sea fans will be reviewed in the context of major sea-level changes such as the Messinian Salinity Crisis of the Paratethys or the observation of often Quaternary sea-level fluctuations. We discuss the interplay between the long-term tendency of the natural system and recent or anthropogenic induced changes, and their general feedback. The system mechanics will be described by reviewing and integrating a number of key numerical modelling studies focussed on the evolution of vertical movements in the Carpathians and their foreland coupled with the main moments of basins connectivity and gateway evolution.

\section{Tectonic configuration and vertical movements of the source to sink system}

Out-of-sequence contractional deformation was widespread during the Miocene continental collision of Mediterranean orogens. The coeval retreat of Calabrian, Vrancea, Aegean or Gibraltar slabs (Faccenna et al., 
2004; Ismail-Zadeh et al., 2012) was accommodated by the formation of large extensional basins in their hinterland (e.g., Pannonian and Aegean basins, Black Sea or Western Mediterranean). These basins are extensional back-arcs in terms of geodynamic evolution (Doglioni et al., 2007; Horváth et al., 2006; Okay et al., 1994), although their relative position behind a magmatic or island-arc (Uyeda and Kanamori, 1979) is not always clear. Their rapid evolution by translations and large-scale rotations is a local process that cannot be locally accommodated by the $\mathrm{N}-\mathrm{S}$ absolute plate motion of Africa relative to Europe (Kreemer et al., 2003), such as the E-wards roll-back of Carpathians and Apennines or the $\mathrm{W}$-ward roll-back of the Betics-Rif system (Faccenna et al., 2004; Matenco et al., 2010; Vergés and Fernàndez, 2012). The impact of tectonic processes associated with such roll-back mechanics is significant in terms of dynamic topography, rapid changes in fluvial systems and geo-hazards (Govers and Wortel, 2005; Syvitski et al., 2009).

A good illustration of such processes is the evolution of sedimentary basins presently situated along the Danube River and its catchment area. This fluvial system crosses a number of mountain chains along gateways on its way from the Pannonian and Transylvanian back-arc basins, through the Carpathians and their foreland Dacian Basin towards the main depositional sink of the system, the Black Sea (Fig. 2). The post-Paleogene evolution of these sedimentary basins was largely influenced by the aftermath of back-arc extension and continental collision that took place in the Carpatho-Balkans and Dinarides orogens (Cloetingh et al., 2004; Horváth et al., 2006; Matenco and Radivojević, 2012). The double curvature of the Carpatho-Balkans and the Dinarides Mountains (Fig. 2) formed in response to a Triassic to Tertiary evolution of continental units and intervening oceans. Two intervening oceans (Neotethys and Alpine Tethys) separated a number of continental units by their gradual opening and enlargement (Fig. 1). These oceans closed subsequently by subduction and collision during CretaceousMiocene times (Schmid et al., 2008).

\subsection{Exhumation of the Carpatho-Balkans and evolution of their foredeep}

The Cretaceous-Paleogene convergence of the Carpatho-Balkanides and Dinarides was followed by the Miocene formation and evolution of internal Pannonian-Transylvanian basins (Figs. 1 and 2). The Pannonian basin extension was driven by the rapid Miocene closure by slab-retreat of the Carpathians embayment, a thinned continental to oceanic domain separating the intra-Carpathians units from the European continent (Horváth et al., 2006; Schmid et al., 2008; Ustaszewski et al., 2008). This closure culminated during the 11-8 Ma final moments of Carpathians collision and was followed in the SE Carpathians by subsidence and differential vertical motions during latest Miocene-Quaternary times, a process that is still active today (Ismail-Zadeh et al., 2012; Matenco et al., 2010 and references therein).

Low-temperature thermochronological studies (fission tracks, zircon - ZFT, apatite - AFT, and U-Th/He) have demonstrated that the Miocene-Quaternary exhumation of the Carpathian Mountains is generally limited to 5-6 km (Fig. 3), with few local exceptions at transcurrent contacts in the West and East Carpathians (Danisik et al., 2012; Merten, 2011 and references therein). The exhumation started during Oligocene-Early Miocene times and peaked during last collisional stages at 15-8 Ma by deforming the external thin-skinned nappes and uplifting the orogenic core (Fig. 3a,d, Bocin et al., 2005; Matenco et al., 2010). The same pattern is observed in the South Carpathians, although with significantly reduced values (Fig. 3c,d). The SE Carpathians exhumation patterns are different, the fairly low Miocene values in their internal parts contrast with the up to $6 \mathrm{~km}$ observed in their external nappes (Fig. 3b,d). In more details, higher resolution studies have demonstrated that exhumation migrated in time towards the foreland, ages decreasing from Cretaceous in the internal basement nappes to Miocene-Quaternary in the external thin skinned wedge (Merten et al., 2010). The exhumation rates increased from $\sim 0.8 \mathrm{~mm} /$ year during the Miocene to much higher $1.6-1.7 \mathrm{~mm} /$ year values during the latest
Miocene-Early Pliocene and Pleistocene tectonic events (Fig. 4). This took place in response to a transition from thin-skinned to thickskinned tectonics during and after the final phases of collision driven by the evolution of the Carpathian slab (Fig. 4, Matenco et al., 2007; Merten et al., 2010). These processes are still active today in shifting the high topography towards the foreland and modifying the associated fluvial network (ter Borgh, 2013). The combination between the rapid SE Carpathians exhumation and the continuous subsidence of the Focsani Basin has created an unusual foreland geometry (Fig. 4) that reaches anomalous high values of up to $13 \mathrm{~km}$ (Figs. 3 and 4 , Tărăpoancă et al., 2004). The subsidence created by the evolution of the Vrancea slab affected a much larger area in the Moesian platform at the exterior of SE and South Carpathians, which resulted in sedimentation gradually covering external orogenic units (Krézsek et al., 2013). These uppermost Miocene-Quaternary sediments compose the Dacian Basin of the Eastern Paratethys situated at the exterior of the Carpathians (Fig. 2, Jipa and Olariu, 2013).

The last tectonic event driving the bulk of South Carpathians exhumation (Fig. 3c) took place during Late Cretaceous-Paleogene times (Fügenschuh and Schmid, 2005; Merten, 2011 and references therein). An event of Eocene orogen parallel extension was followed by the formation of the large Cerna-Jiu and Timok faults system cumulating $\sim 100 \mathrm{~km}$ dextral offset in respect to Moesia (Fig. 1, Fügenschuh and Schmid, 2005; Schmid et al., 2008). This transtension has migrated Ewards along the foreland of the South Carpathians during the Oligocene-Early Miocene (Krézsek et al., 2013). It resulted in extensional subsidence and continental to shallow marine sedimentation overlying the internal parts of the South Carpathians that are presently situated at high elevations (Matenco and Schmid, 1999). These events were followed by Middle-Late Miocene transpressional docking of the South Carpathians and their thrusting over the Moesian platform. This was associated with much lower amounts of exhumation when compared with the East/SE Carpathians (Fig. 3c,d). A larger number of AFT ages distributed throughout the Miocene have been obtained in the western part of the South Carpathians, near their connecting area with the Balkanides (Bojar et al., 1998).

The Balkanides units share a common Cretaceous tectonic history with the South Carpathians, a first late Early Cretaceous period of nappe stacking was followed by Late Cretaceous back-arc extension and associated magmatism ( 93-72 Ma, Gallhofer et al., 2015; von Quadt et al., 2005), reduced latest Cretaceous shortening and thrusting of external nappes during Eocene times (Fig. 1, Ivanov, 1988). Their internal units were subsequently affected by an event of Oligocene-Quaternary extension and basins formation (Burchfiel et al., 2008). Although there are almost no low-temperature thermochronological studies in the external Balkanides, their geometry and sedimentary architecture suggest that these mountains were relatively stable and formed the southern margin of the Carpathians foreland basins during their entire Miocene evolution.

\subsection{Evolution of the Pannonian and Transylvanian basins and their link with Dinarides and Carpathians shortening}

The main shortening episodes related to subduction of the Neotethys/ Vardar Ocean and continental collision took place in the Dinarides during Late Jurassic-Eocene times (e.g., Dimitrijević, 1997; Schmid et al., 2008). The area of Dinarides located close or adjacent to the Pannonian Basin was affected by subsequent Miocene extension along a series of detachments associated with crustal-scale footwall exhumation and formation of half-grabens in their hanging-wall (Stojadinovic et al., 2013; Toljić et al., 2013; Ustaszewski et al., 2010). The interpretation of seismic lines in the SE part of the basin (Figs. 4 and 5) shows that the extension was asymmetric and deformation migrated NE and E-wards in space and time across the basin, from Early Miocene to Early Pontian (20 Ma or older to $\sim 8.5 \mathrm{Ma}$ ). The extension ended at the same time with the ceasure of collision in the East and SE Carpathians (Matenco and Radivojević, 


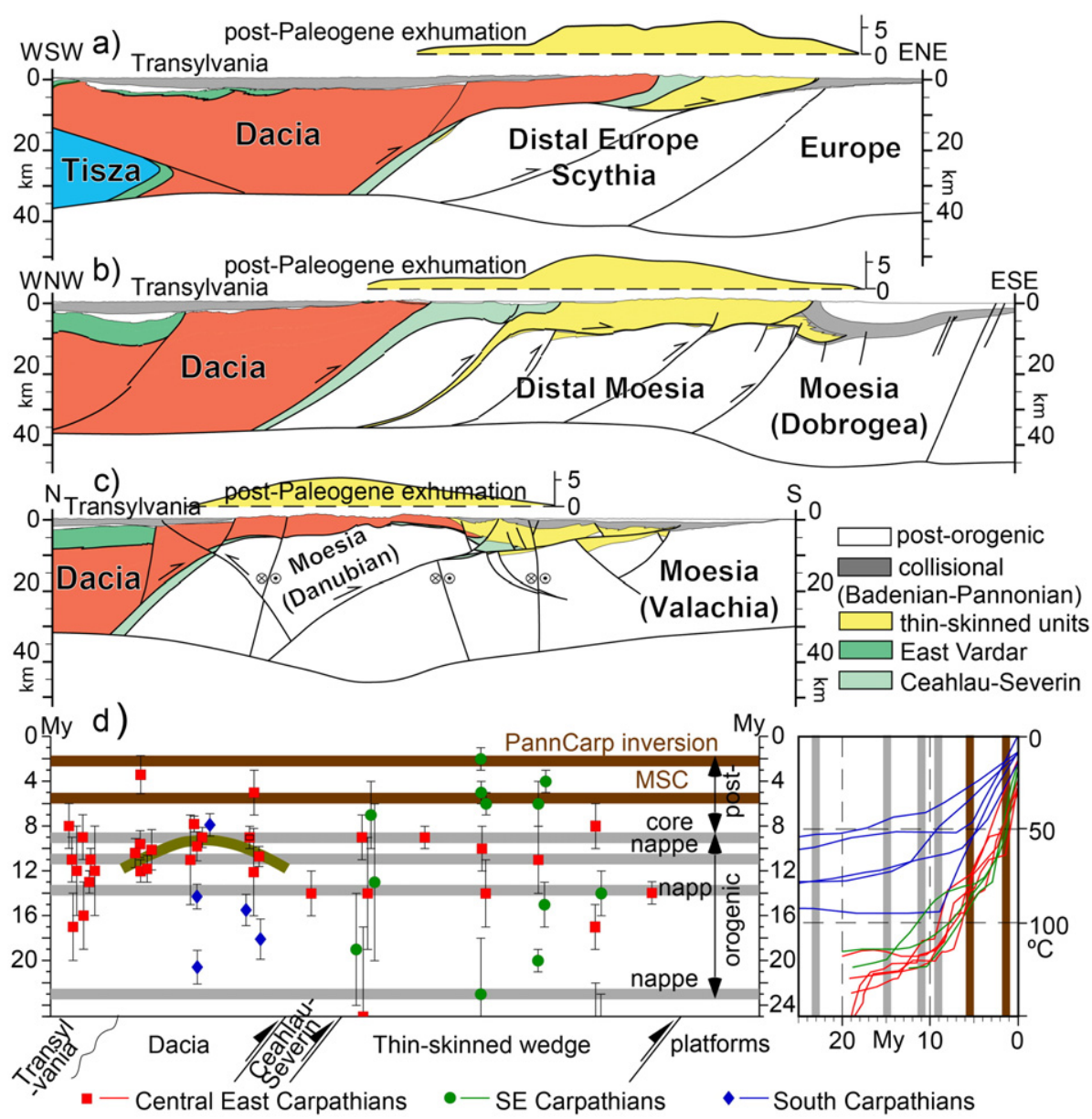

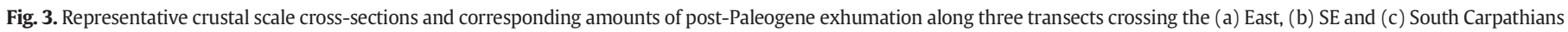

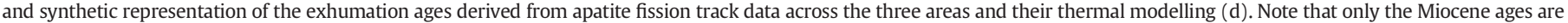
plotted (after Matenco et al., 2010).

2012). The final moment of Late Miocene extension created the largescale mantle lithospheric thinning that is still presently observed beneath the Pannonian Basin (Horváth et al., 2006). This basin was subsequently inverted along numerous thrusts or strike-slip structures, a process that was and is still driven by the indentation of the Adriatic promontory (Bada et al., 2007).

The analysis of kinematic and thermochronological data along a regional profile (Fig. 4) shows that the Miocene contraction and exhumation of the SE Carpathians was indeed coeval with the extension recorded in the SE part of the Pannonian Basin. Balanced crosssections and various reconstructions have inferred a total amount of Carpathians shortening in the order of $120-160 \mathrm{~km}$, increasing from north to south (Ellouz et al., 1994; Morley, 1996; Roure et al., 1993). The amounts of extension in the Tisza-Dacia sector of the Pannonian Basin are variable due to the coeval clockwise rotational kinematics, decreasing SE-wards from the Mid-Hungarian Shear Zone (Fig. 1), but available estimates indicate $140-180 \mathrm{~km}$ near the latter (Lenkey, 1999; Ustaszewski et al., 2008). Similar amounts of extension and contraction indicate that there was no large-scale absolute plate motion involved in the Miocene shortening of the Carpathians, contraction at the exterior of the orogen being entirely accommodated by back-arc extension (Fig. 4). In other words, the Apuseni Mountains, Transylvanian Basin, East, SE and South Carpathians simply rotated clockwise and moved E-wards into the Carpathian embayment, driven solely by the pull and sink of the slab roll-back, in agreement with the overall $\mathrm{N}$ ward movement of Africa relative to Europe during Miocene times (Kreemer et al., 2003).
One of the most striking European examples of dynamic topography (i.e. deep mantle driven) is the Miocene evolution of the Transylvanian Basin (Figs. 2 and 4). The up to $3.5 \mathrm{~km}$ thick Middle-Upper Miocene sedimentary cover has an apparent symmetric geometry both in crosssections and in map view (Figs. 1 and 4). The onset of regional subsidence in the Transylvanian Basin took place during Middle Miocene times, continuing with accelerated pulses throughout the Middle-Late Miocene (Krézsek and Filipescu, 2005). This subsidence started near the East and SE Carpathians and gradually extended over the entire basin (Tiliţă et al., 2013). In parallel, the Middle-Late Miocene exhumation of neighbouring Carpathians uplifted the basin margins in several pulses (Matenco et al., 2010), interrupted by a Middle Miocene eustatic sea level drop (de Leeuw et al., 2010) that lead to the deposition of an evaporitic sequence throughout the basin. The salt migrated during the latest Middle-Late Miocene and created locally large exaggerated diapirs (Krézsek and Bally, 2006; Tiliţă et al., 2013). The entire basin was uplifted at $\sim 8 \mathrm{Ma}$ to the $\sim 600 \mathrm{~m}$ present maximum topographic elevation, being subsequently affected by erosion and continental deposition (Matenco et al., 2010).

The Miocene vertical movements of the Transylvanian Basin cannot be explained by genetic related structures, such as large faults (Fig. 4). Both the initial subsidence and the subsequent regional exhumation are dynamic topography processes, most likely related to the deep mantle evolution of the Carpathian slab. It is rather unclear exactly which process may be responsible for the initial subsidence from the wide variety inferred, although some are more likely, such as mantle thinning during extension (Tiliţă et al., 2013). Furthermore, the evolution of the 


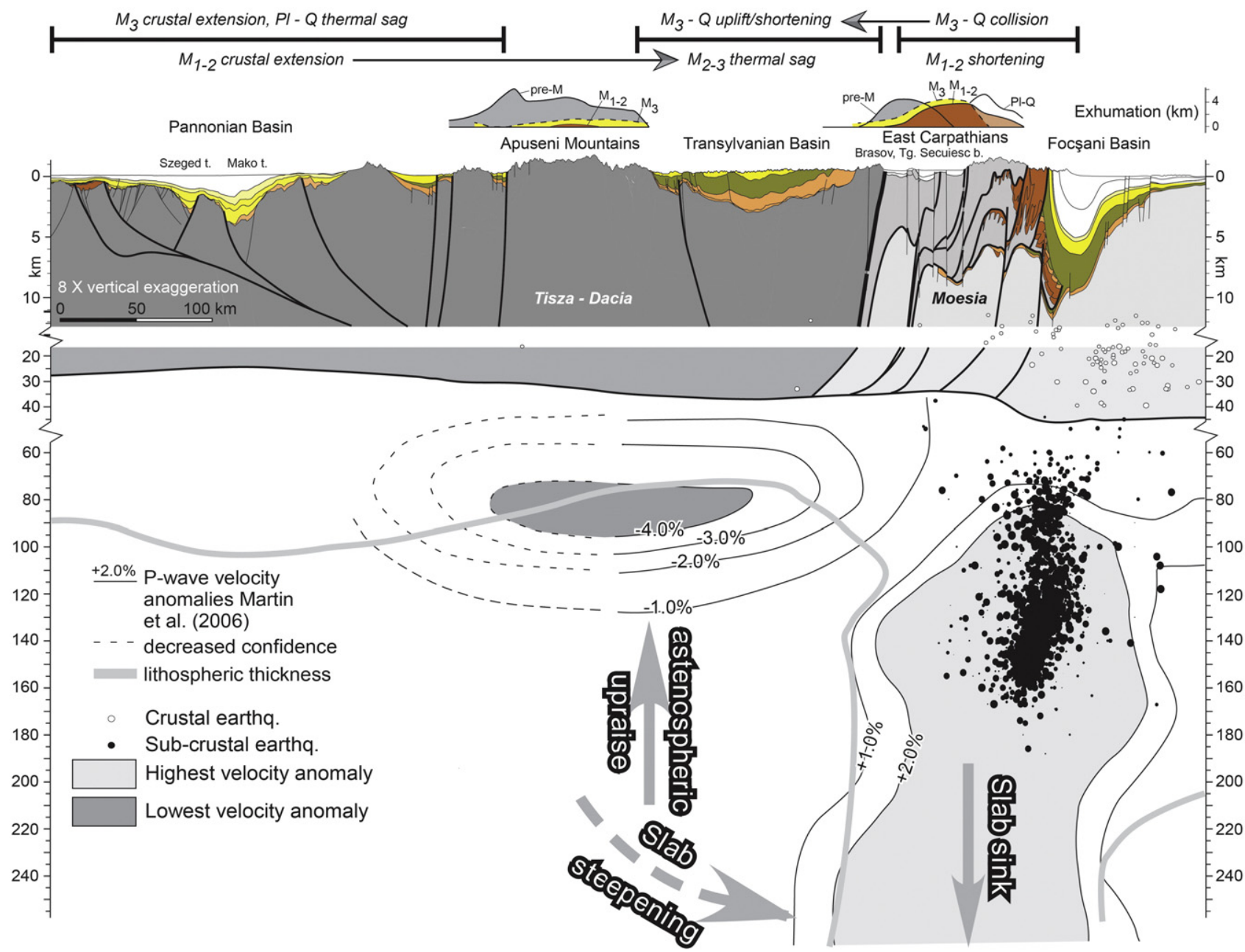

pre-Miocene thin-skinned Sarmatian $\mid$ Middle Miocene Meotian/Pannonian - Middle Pontian (Upper Miocene) \begin{tabular}{l|l} 
Upper Pontian & Pliocene - Quaternary
\end{tabular}

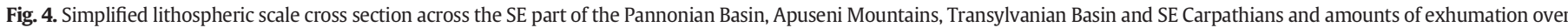

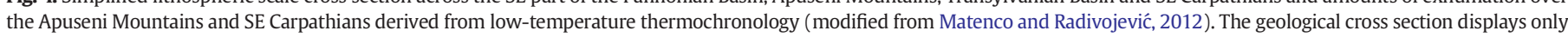

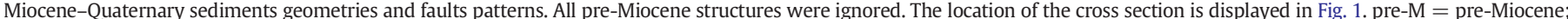

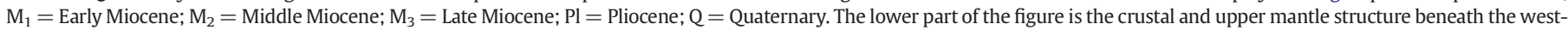

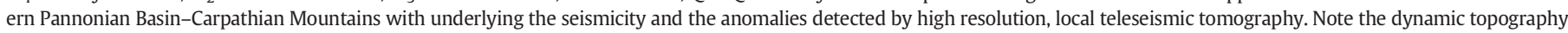
associated both with the Vrancea slab and with the post-Miocene uplift of the Transylvanian Basin associated with the asthenospheric upraise.

adjacent intramontane Pliocene-Quaternary Brasov and Tg.-Secuiesc basins (Figs. 1 and 4 ) and the associated alkaline and adakitic volcanism is also driven by the rise of the astenospheric mantle in the hinterland of the rapidly sinking Vrancea slab (Ismail-Zadeh et al., 2012; Seghedi et al., 2011). Therefore, the high topography of the Transylvanian and smaller neighbouring basins is a response to active upwelling of the asthenosphere in the hinterland of the Vrancea slab (Fig. 4). This resulted in a presently still active migration of the fluvial network that crosses the Apuseni Mountains and their northern prolongation (Fig. 2, Dombrádi et al., 2007; ter Borgh, 2013).

\subsection{Formation and recent evolution of the Black Sea sink}

The Black Sea is a back-arc basin controlled by the subduction of the Neotethys Ocean beneath the Rhodope-Pontides Arc (Letouzey et al., 1977; Okay et al., 1994). Two sub-basins opened gradually during the Cretaceous-Middle Eocene moments of extension resulting in an oceanic crust overlain by an up to $15 \mathrm{~km}$ thick sedimentary sequence in their centre (Graham et al., 2013; Nikishin et al., 2015). The extension opened the western sub-basin during Cretaceous times, continued during the Eocene and was subsequently followed by the onset of regional inversion starting with the late Middle Eocene (Dinu et al., 2005; Munteanu et al., 2011; Okay et al., 1994). The inversion migrated $\mathrm{N}$-wards throughout Late Eocene-Miocene times in the western Black Sea, cumulating 30-40 km of shortening. This shortening changed polarity along the basin strike, from north-vergent in the west to south-vergent in the east, as inferred by observations and analogue modelling studies (e.g., Munteanu et al., 2011; Munteanu et al., 2013; Munteanu et al., 2014).

This tectonic history is the background of higher resolution depositional changes related with sea-level fluctuations, rapid changes in sedimentation rates and deltaic sedimentation that took place during the Pliocene-Quaternary in the western Black Sea (Gillet et al., 2007; Lericolais et al., 2009; Popescu et al., 2001). These changes are related to the endemic and endorheic evolution of the Black Sea in the larger framework of the Eastern Paratethys, its present-day connection with the Mediterranean being Holocene in age (Hiscott et al., 2007). Local and regional unconformities formed in response to high-frequency sea-level fluctuations, in particularly well mapped in the deep-sea fans 

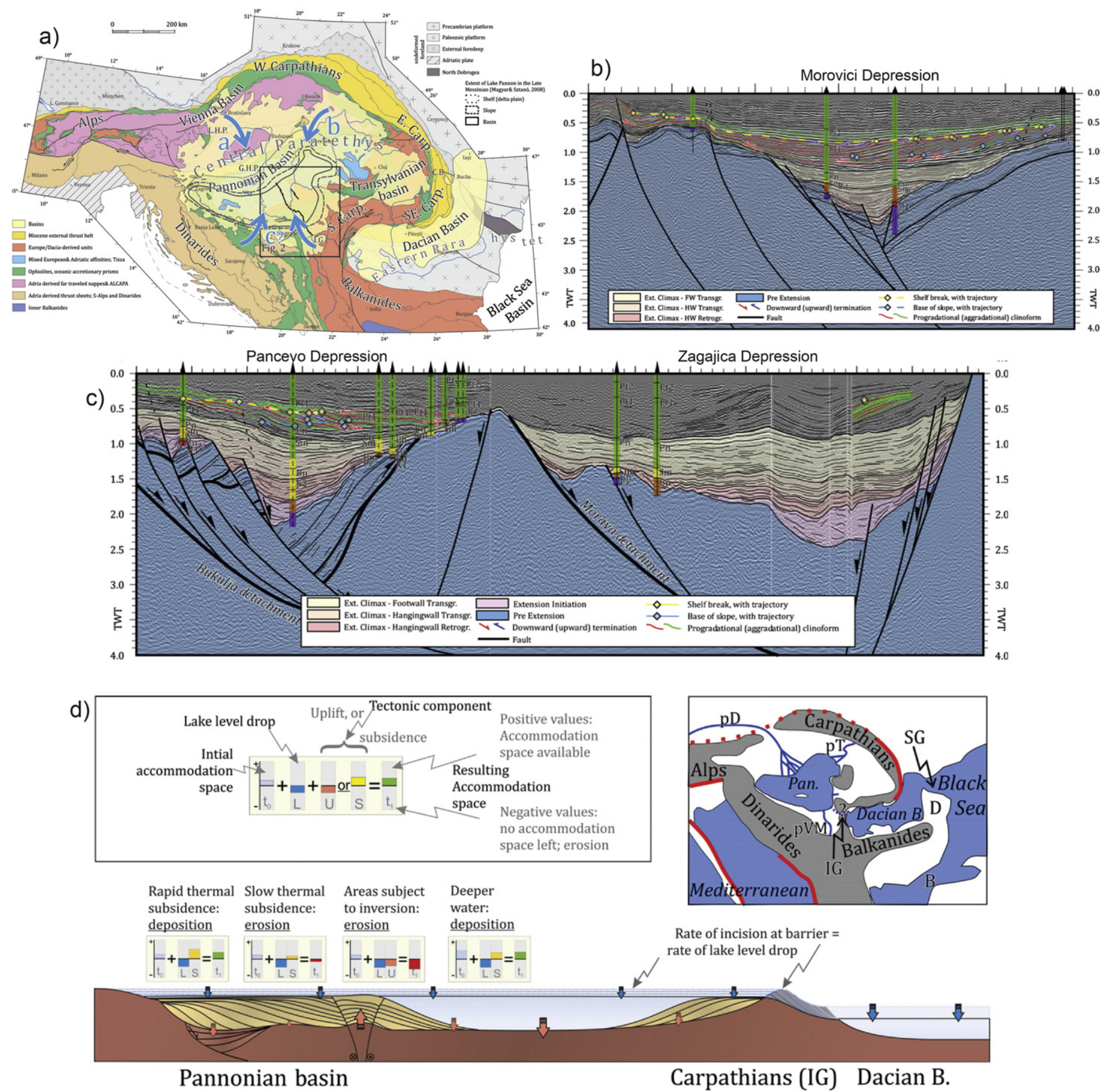

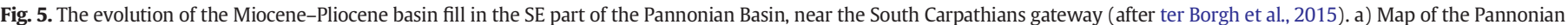

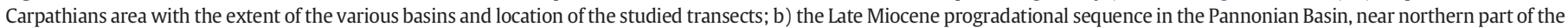

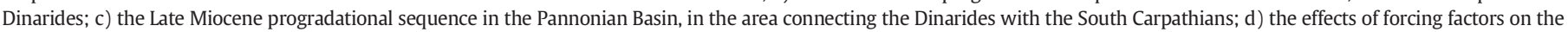

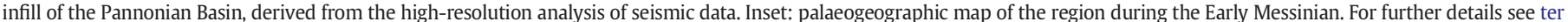
Borgh et al. (2015) and Matenco and Radivojević (2012).

located in the front of major deltas, such as Danube, Dniepr or Sakarya (Dinu et al., 2005; Dondurur et al., 2013; Gillet et al., 2007; Lericolais et al., 2013). Large-scale erosion took place at or near the transition between Miocene and Pliocene times, which is also the time of the Messinian Salinity Crisis (MSC) of the Mediterranean. The erosion was documented by multiple seismic interpretation studies calibrated by biostratigraphy in exploration wells and locally reaches kilometres in size by incising along deep canyons the pre-existing sediments of the Black Sea (e.g., Dinu et al., 2005; Dondurur et al., 2013; Munteanu et al., 2012; Nikishin et al., 2015; Tari et al., 2009).

\section{The evolution of Carpathian basins and their separating gateways}

The Oligocene-Early Miocene onset of extension in Pannonian Basin areas situated adjacent to the Dinarides and South Carpathians has resulted in the deposition of continental alluvial to lacustrine endemic sediments. This was followed by enhanced subsidence during the Middle Miocene extension, when the Pannonian Basin became connected to the marine domain situated at the exterior of the Carpathians (Matenco and Radivojević, 2012; Rögl, 1999). The subsequent Miocene exhumation of the Carpathian Mountains has separated their foreland basins 
from the Pannonian/Transylvanian realm. The complete isolation of the latter was marked by the development of endemic lacustrine sedimentation during Pannonian times (e.g., Magyar et al., 1999). Magnetostratigraphic and absolute age dating suggested that this isolation took place between 11.7-11.3 Ma most likely in two steps, at first by the separation of the Pannonian Basin followed $~ 0.4$ Ky later by the separation of the Transylvanian Basin (ter Borgh, 2013; ter Borgh et al., 2013 and references therein). The isolation of the Pannonian basin ended towards the end of the Miocene times, when uni-directional migration of Pontian fauna from the Pannonian Basin is recognized in the entire Eastern Paratethys. At higher resolution, numerous short-lived ingression events of marine or endemic fauna have been recognized in the Carpathians foreland (Stoica et al., 2013; ter Borgh et al., 2014).

This overall connectivity interplay between the back-arc and foreland basins suggested at first connection by regional subsidence and isolation by orogenic uplift, followed by re-connection either by subsidence or erosion of the barrier separating these basins. Continuous Miocene exhumation took placed in the East and SE Carpathians, while the latter was affected by latest Miocene-Pliocene subsidence and Pliocene-Quaternary uplift. Exhumation studies indicated that the Apuseni Mountains were already exhumed and did not recorded significant vertical movements during post-Paleogene times (Merten et al., 2011). Therefore, the areas that recorded significant differential vertical movements potentially interesting to connectivity events are the South Carpathians during the Oligocene-Miocene and the SE Carpathians during the latest Miocene and younger events.

\subsection{Opening and filling the SE part of the Pannonian Basin}

The SE Pannonian Basin area adjacent to the South Carpathians and Dinarides was recently analysed in the regional study of Matenco and Radivojević (2012) and in the high-resolution study of ter Borgh et al. (2015) (Fig. 5). The formation of half-grabens was accompanied by large-scale extensional exhumation in the footwall of detachments buried beneath the Miocene sediments (such as Bukulja or Morava detachments, Fig. 5c). Their hanging-wall geometry formed half-grabens (e.g., Pancevo Depression) or more symmetric-looking geometries (e.g., Zagajica Depression, Fig. 5c). The latter is just apparent, as the larger scale footwall exhumation along the main Morava

detachment has been subsequently followed by a late stage normal fault on the eastern flank of the basin. One other typical geometry is the apparent symmetrical structure with low-angles dipping flanks (e.g., Morovici Depression, Fig. 5b). Here, the syn-kinematic fill is asymmetric and indicates a migration in time of normal faulting in the halfgraben, accompanied with footwall erosion. Such symmetric-looking low-angle structures with asymmetric basin fill are common in the Pannonian Basin, where crustal detachments were demonstrated near the Alps (Tari et al., 1992) or speculated in the SE Pannonian Basin (the Mako trough, Fig. 4, Magyar et al., 2006). Here, the extension started during the Oligocene-Early Miocene near the Dinarides, continued everywhere in the basin during the Middle Miocene and ceased during Late Miocene times in an area close to the Apuseni Mountains and South Carpathians (Fig. 4). The first and last stages of extension were associated with the formation of detachments and half-grabens, while the second Middle Miocene extension resulted in the widespread formation of more symmetric grabens.

The upper infill shows a large-scale progradation (Fig. 5c), generated by building of the first shelf-margin slope in the NW Pannonian Basin at $\sim 10 \mathrm{Ma}$ and its migration $400 \mathrm{~km}$ to the SE and S roughly along the present day trace of the Danube and Tisza rivers at a rate of $\sim 70 \mathrm{~km} / \mathrm{Ma}$ slope advance until $4 \mathrm{Ma}$ (Magyar et al., 2013).

The higher resolution study of ter Borgh et al. (2015) suggested that the syn-kinematic sedimentation is associated with phases of normal faulting by forming typical progradational-retrogradational sequences during an overall rifting cycle transition from initiation, climax to post-rift (Fig. 5b,c, see also ter Borgh, 2013). The progradation in the upper part of the basin fill was asymmetric, dominantly from the $\mathrm{N}$ and NW, but was associated with shorter progradation patterns from the E, SE and S (Fig. 5a). The cyclicity observed in the progradation pattern shows that fluctuations of the lake level had limited amplitudes, being influenced by pre-existing extensional geometry of (half-)grabens or uplifted areas, and by the continuous thermal sag, in particular large in the SE part of the basin (Fig. 5d). The outflow at the South Carpathians barrier and decrease of the lake level drop due to its erosion that started likely at around $8 \mathrm{Ma}$ was one other factor influencing sedimentation. When adding the significant climatic variations that took place during progradation, the result is a complex interplay of parameters influencing the accommodation space (Fig. 5d). The rates of all internal and external forcing factors were often in the same order of magnitude and cumulated changes in the order of tens to a couple of hundreds of metres. Given this fine interplay, the MSC effects cannot be discriminated in this part of the basin, given the $\sim 25-50 \mathrm{~m}$ seismic resolution (Fig. 5d).

\subsection{Basin deformation and infill between the South Carpathians and Balkans}

A representative wide-angle (i.e. deep imaging) seismic reflection profile illustrating the mechanical interplay between the South Carpathians and their foreland is available in the study of Krézsek et al. (2013) (Fig. 6). The profile illustrates the oblique emplacement of the South Carpathians thin-skinned wedge (i.e. the Getic Depression) overlain by sediments of the Dacian Basin. The total amount of shortening is in the order of $30 \mathrm{~km}$. The Middle-Late Miocene thrusting peaked at around $14 \mathrm{Ma}$ and $11 \mathrm{Ma}$, as evident from the syn-kinematic wedgeshaped deposition. This was followed by regional subsidence affecting the entire foreland during the latest Miocene-Quaternary, resulting in a gradual transgression and sedimentation over the thin skinned wedge (Fig. 6). The initial frontal emplacement was followed by outof-sequence deformation that uplifted and eroded large internal and central parts of the thin-skinned wedge. Note that instead of normal faulting in the internal part of the wedge (near Govora Fault in Fig. 6) the alternative interpretation of coeval thrusting deformation is more likely given field structures and syn-kinematic sedimentation (Răbăgia et al., 2011). This phase of out-of-sequence thrusting and transpression took place during the latest Miocene (Late Sarmatian-Early Meotian at around 9-8 Ma), which is roughly coeval with the last moment of thrusting and exhumation in the East and SE Carpathians. The last tectonic deformation is recent, when Pliocene strata were tilted either by folding or by the general uplift of South Carpathians (Fig. 6, see also Răbăgia et al., 2011), coeval with the much larger differential vertical movements affecting the SE Carpathians. Summarizing, four main moments of tectonic uplift took place in the South Carpathians and their foreland (at around 14, 11, 9-8 Ma and in post-Pliocene times) and were juxtaposed after 11 Ma over the much wider subsidence that affected the entire Moesian platform.

The evolution of accommodation space in the Moesian platform area adjacent to South Carpathians was analysed in the study of Leever et al. (2010). One reflection seismic transect has been chosen to connect two differently oriented areas of the South Carpathians (Fig. 7a). This profile ends at the outlet of the Danube River crossing the South Carpathians and is adjacent to the previously described SE part of Pannonian Basin across the mountain chain. The interpretation shows two local depocentres filled by a progradation system organized in two stratigraphic sequences (Upper Meotian-Lower Pontian and post-Middle Pontian) separated by erosional unconformities and their correlative conformities in the deeper part of the basin (Fig. 7b). These sequences formed due to eustatic changes, either variation of the local water budget in the isolated basin (i.e. the balance between water influx and evapo-transpiration) or regional sea-level changes (i.e. affecting also the surrounding Paratethys basins). The onset of the second sequence took place at or near the MSC times and implies a sea-level drop in 


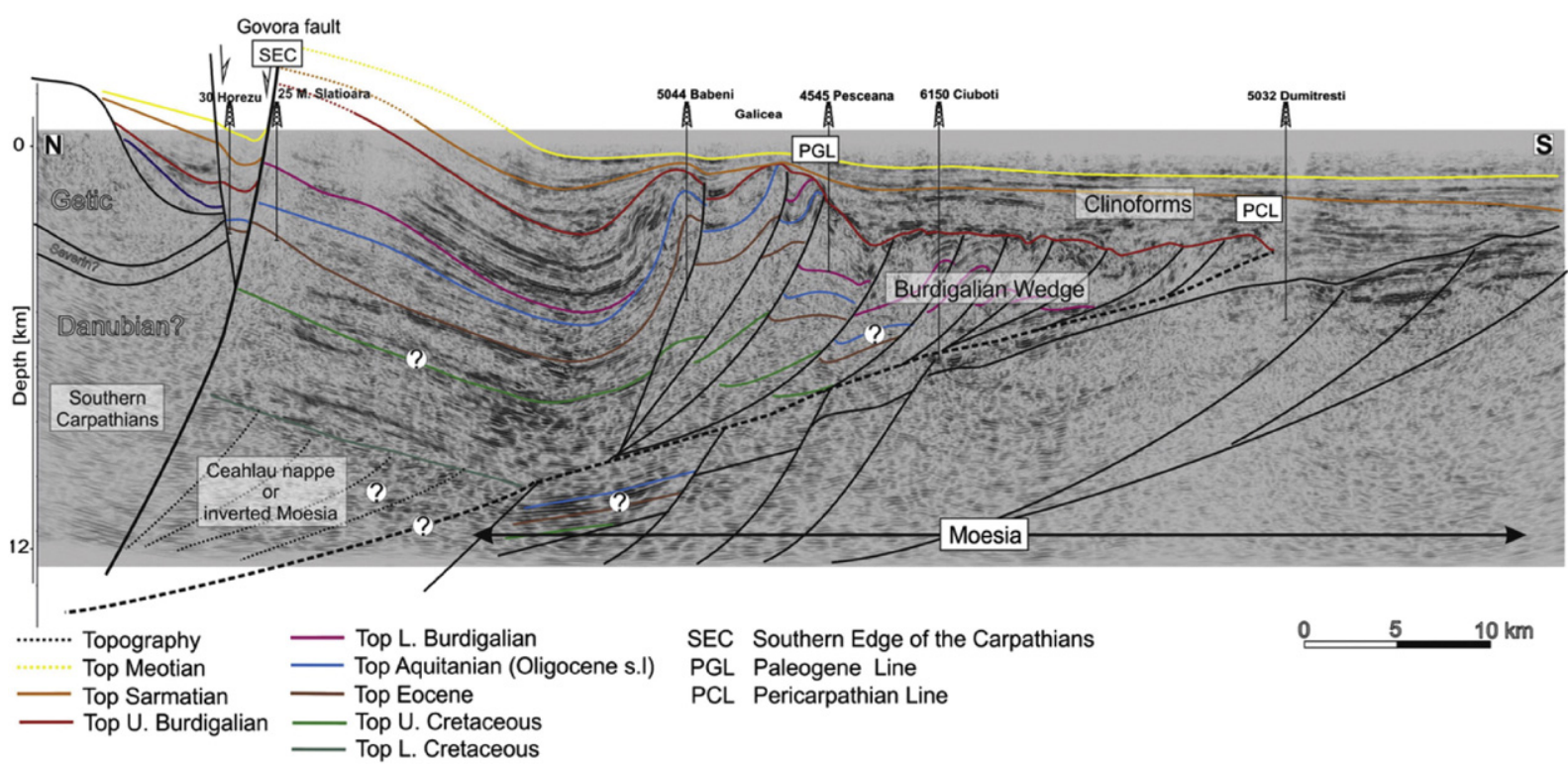

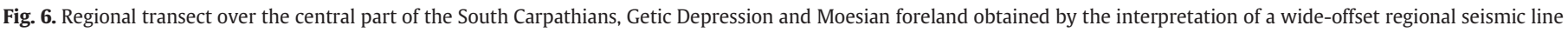
(after Krézsek et al., 2013).

the order of $200 \mathrm{~m}$ in the Dacian Basin. By correlating with the roughly coeval moments of sea-level drop with different amplitudes proposed for the Pannonian Basin and the Black Sea, the study proposes a connectivity model in which the different amplitudes are driven by the separating barriers and their erosion during the sea-level drop (Fig. 7c). Once the sea level of the Black Sea had dropped below the level of the Scythian gateway, its erosion is the main parameter that controls the
Dacian Basin sea level. A positive water balance in the Dacian Basin explains the long period of sea-level drop during the low-stand. The same mechanism is implied for the connection between the Dacian and the upstream Pannonian basins, the MSC sea-level drop of the latter being lower or equal. Interesting is that the progradation in the basin is asymmetric with respect to the position relative to the mountain chain. The Upper Meotian-Lower Dacian progradation is $\sim 70 \mathrm{~km}$ long in front of
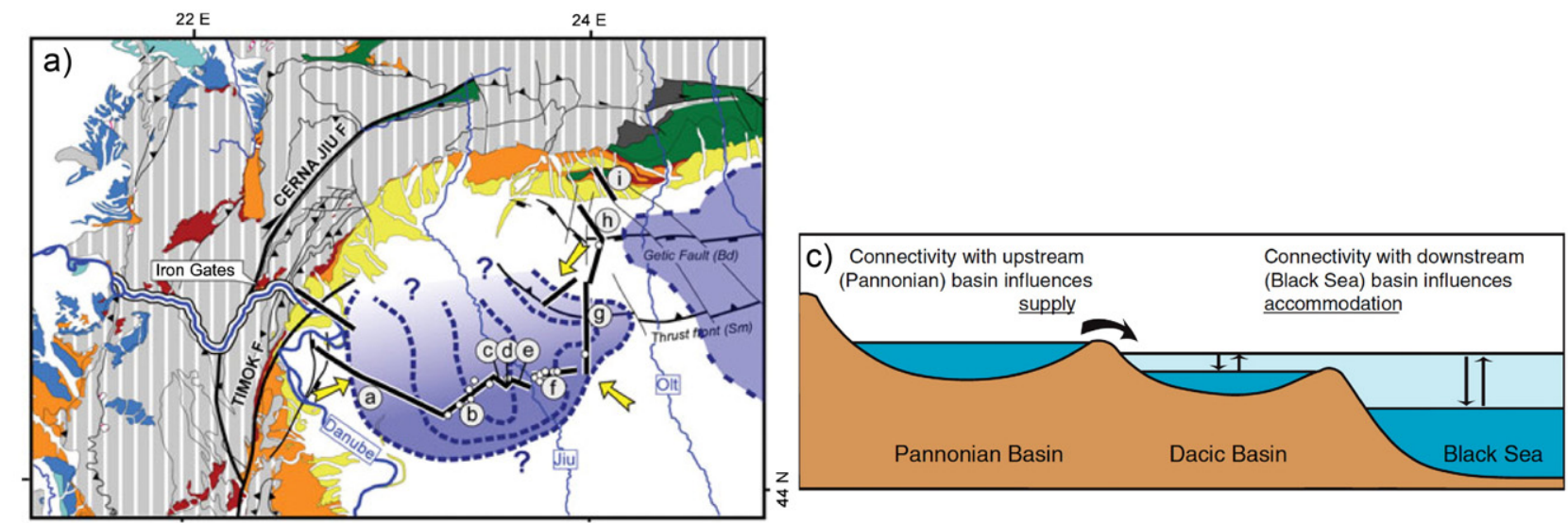

b)

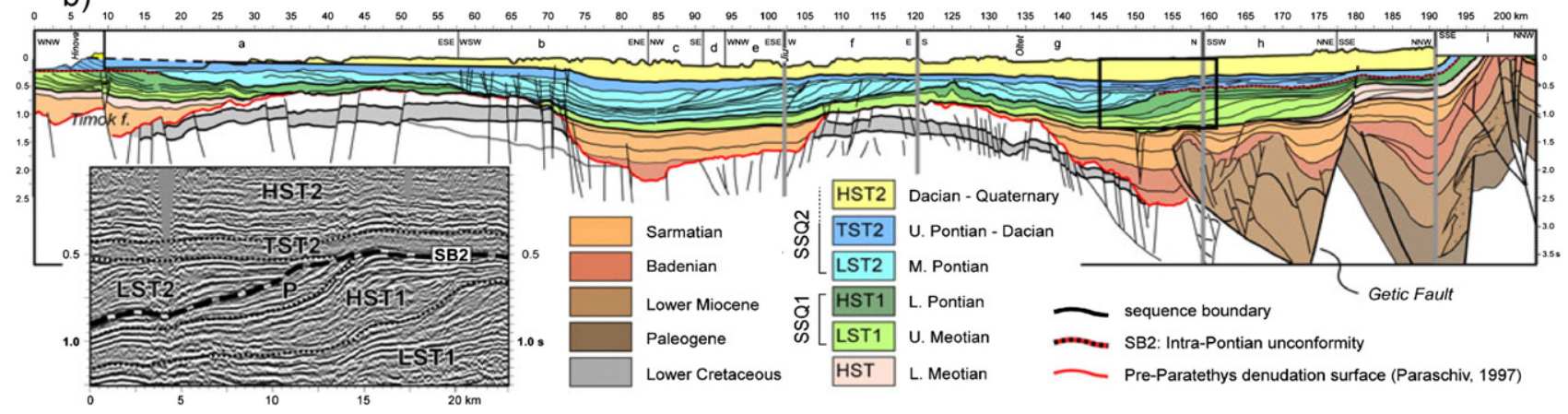

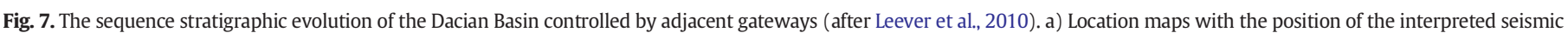

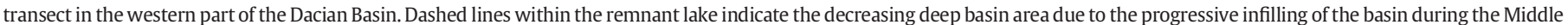

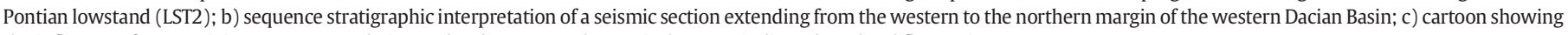
the influence of connectivity on accommodation and sediment supply. Vertical arrows indicate base level fluctuations. 
the Danube outlet at Iron Gates, while elsewhere in the profile is less than half in size. Our own observations in seismic lines indicate that the average coeval progradation elsewhere in the basin is in the order of $10-30 \mathrm{~km}$, confirming the asymmetry. This is valid even when compared with areas located E-wards, which recorded higher tectonic exhumation during the Miocene-Quaternary shortening and, therefore, created more erosion in the South Carpathians. All these observations point to a much larger source area for the progradation located in front of the Danube outlet, implying a connection with the Pannonian Basin. This reasoning has obvious limitations, such as the resolution of seismic lines or mechanisms generating progradation slopes.

The connectivity hypothesis has been tested in the Dacian Basin area of the Iron Gates outlet by the high-resolution study of ter Borgh et al. (2014) (Fig. 8). This area was affected by the large $\sim 65 \mathrm{~km}$ Miocene offset of the Timok Fault that was at first transtensional followed by transpression (Fig. 8a). Based on outcrop observations combined with seismic interpretation, the study has demonstrated the link between South Carpathians vertical movements and depositional geometries in the neighbouring Dacian Basin. A number of events were driven by tectonics and, to a lesser extent, by regional sea-level variations (Fig. 8b). A two-way connection between the Pannonian Basin and the region that would become the Dacian Basin existed during the Middle Miocene (Late Badenian, until $11.7 \mathrm{Ma}$ ). The area was affected by a relative sealevel drop and the formation of a Late Miocene (Late Sarmatian-Early Meotian) unconformity starting at $\sim 11.7 \mathrm{Ma}$. This is the main moment when the Getic Depression was affected by shortening, at first by emplacement of the main nappe and later by out-of-sequence thrusting (Fig. 6). This is also when the main uplift of the East and SE Carpathians was recorded. The result was the formation of this regional unconformity, otherwise commonly observed along the Carpathian Mountains. The study infers subsequent moments of short-lived connection between the Pannonian and Dacian basins that were likely in one direction (i.e. from the Pannonian to the Dacian). In latest Miocene (Pontian) times, an initial transgression event was followed by a regional sea-level fall, whose amplitudes are in the order of 50-200 m, although a realistic value is likely in the lower part of this spectrum and, therefore, lower than the ones inferred by the study of Leever et al. (2010). The asymmetric Late Miocene-earliest Pliocene progradation in front of the Iron Gates is not accompanied by significant environmental changes until Pontian times, when fauna became common in the Central and Eastern Paratethys.

\subsection{Modelling the connection between the Pannonian and Dacian basins}

The connectivity between the Pannonian and Dacian basins by a gateway located in the intervening area of the South Carpathians was modelled in the study of Leever et al. (2011) (Fig. 9). This study used a pseudo-3D (planform) forward difference code in which tectonics, surface processes and flexural isostasy are fully coupled (GarciaCastellanos, 2002). The model accounts for the interaction between surface processes, sedimentation and their lithospheric scale response in terms of vertical motions on large spatial and temporal scales. Therefore, it allows only first order predictions on the evolution of gateways or connectivity events between sedimentary basins. In the model setup (Fig. 9b), the Pannonian and Dacian basins are in restricted connection over a separating topographic high that simulates the South Carpathians. The Pannonian Basin is restricted on both sides, while water circulation is allowed at the eastern end of the Dacian Basin (Fig. 9b). The model has tested a number of critical parameters, such as the difference between water levels in the two basins, flexural rigidity of the lithosphere underlying the basins controlling the accommodation space via sediment supply, barrier height, or the balance between precipitation and evapo-transpiration. The numerical modelling inferred that the key factors controlling sedimentary response are the upstream (i.e. Pannonian Basin) accommodation space and its elevation at the time of capture. One important parameter is the flexural rigidity that, through its control on accommodation space, has a major influence on depositional geometries and sediment distribution (Fig. 9c). This controls both the timing and the rate of the bulk sediment shift from the upstream to the downstream basin. A strong lithosphere in the upstream basin will lead to a quick shift while in the case of a weak lithosphere the response is more gradual. The model infers that a unidirectional fluvial connection from the Pannonian to the Dacian basins was marked by increased sedimentation rates in front of the gateway, even if the connection occurred before the Pannonian lake was completely filled. In other words, the model predicts that the large scale Late Miocene sedimentation observed in front of the Iron Gates gateway would reflect the connectivity and could have started earlier that the complete fill of the Pannonian Basin at the end of Miocene times. The effects are largely dependent on upstream basin accommodation space left and elevation difference between water levels in the two basins at the time of capture (Fig. 9d). In all cases the time lag between the capture and bulk sedimentation shift is dependent on the underlying lithospheric strength (by the effective elastic thickness Te in Fig. 9d). By comparing the numerical modelling with observations in both basins, the modelling infers that at the time of the basin capture the accommodation space left in the upstream Pannonian Basin was low, the elevation difference between the two water-levels was small and the increase of sedimentation rates took place gradual after a longer time lag (panel lower left in Fig. 9d). The latter was controlled by the low flexural rigidity of lithosphere underlying the Pannonian Basin, resulting from the elevated thermal structure of this extensional domain. Obviously, this regional model cannot fit the much higher resolution of outcrop and seismic studies on both sides of the gateway, such as the prediction of a permanent uni-directional connection between the two basins that it at odds with the episodic influxes of fauna prior to its ultimate generalization in both basins during Pontian times. Similarly, the observed moments of transgression in the Dacian Basin or the fluvial sedimentation that kept balance with the on-going thermal subsidence in the Pannonian Basin were not simulated in this model. But the overall concept of time lag is very important in understanding connectivity: bulk sedimentation shifts can significantly post-date the moment of establishing a connection. Even when the later decreases the accommodation space by eroding the separating barrier, the upstream basin needs time to fill up prior to these bulk sedimentation shifts.

\subsection{Recent subsidence and associated processes in the SE Carpathians foreland}

The external part of the SE and South Carpathians displays atypical foredeep geometries (Figs. 4 and 6). Typical syn-kinematic wedges are observed only in Upper Miocene sediments and were overlain by the thick latest Miocene-Quaternary sedimentation of the Dacian Basin driven by the continuous subsidence of the Moesian platform in postcollisional times (Matenco et al., 2007). The driving mechanisms of this subsidence cannot be quantified by the study of the upper crustal structural geometries, but it is certainly driven by the evolution of the Vrancea slab. High-resolution local tomography and modelling studies have shown that the high-velocity mantle anomaly often associated with the Vrancea slab is much larger, extending from the SE Carpathians in a SW-ward direction well beneath the Moesian platform, and can be divided roughly in two segments (Ismail-Zadeh et al., 2012). While the Vrancea segment is (barely) still attached, the anomaly beneath the Moesian platform is apparently detached from the Moesian lithosphere. This is a typical geometry resulting from a tear propagating along the strike of the slab in what is commonly known as STEP (subductiontransform edge propagator) mechanics (Govers and Wortel, 2005). A lithospheric scale tear in the Carpathians subducting slab propagated along the South Carpathians during Miocene-Quaternary times, eventually arriving in the present day configuration. However, such a hypothesis is still speculative (see Ismail-Zadeh et al., 2012). 


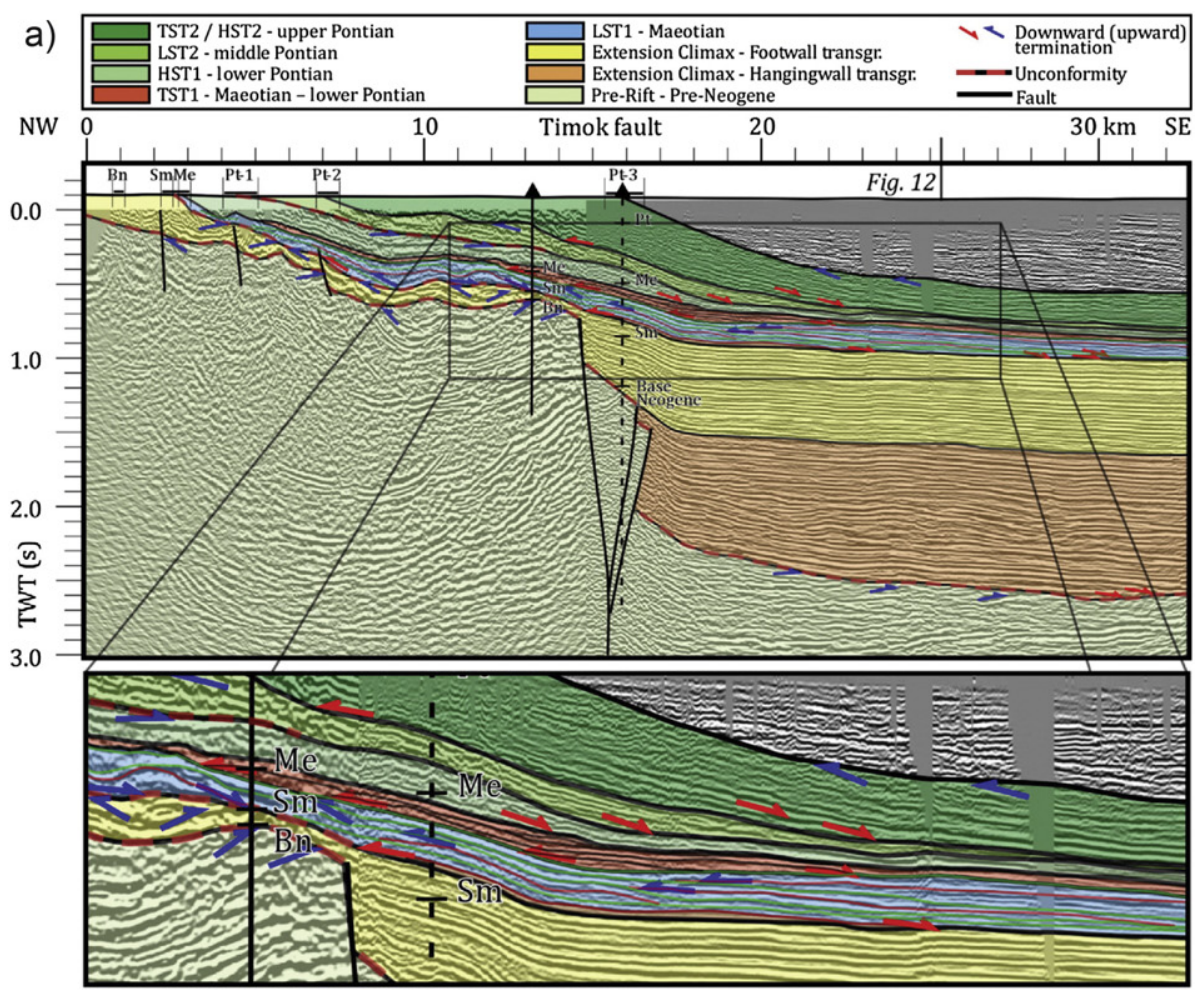

Pannonian Basin

(Central Paratethys)

b)

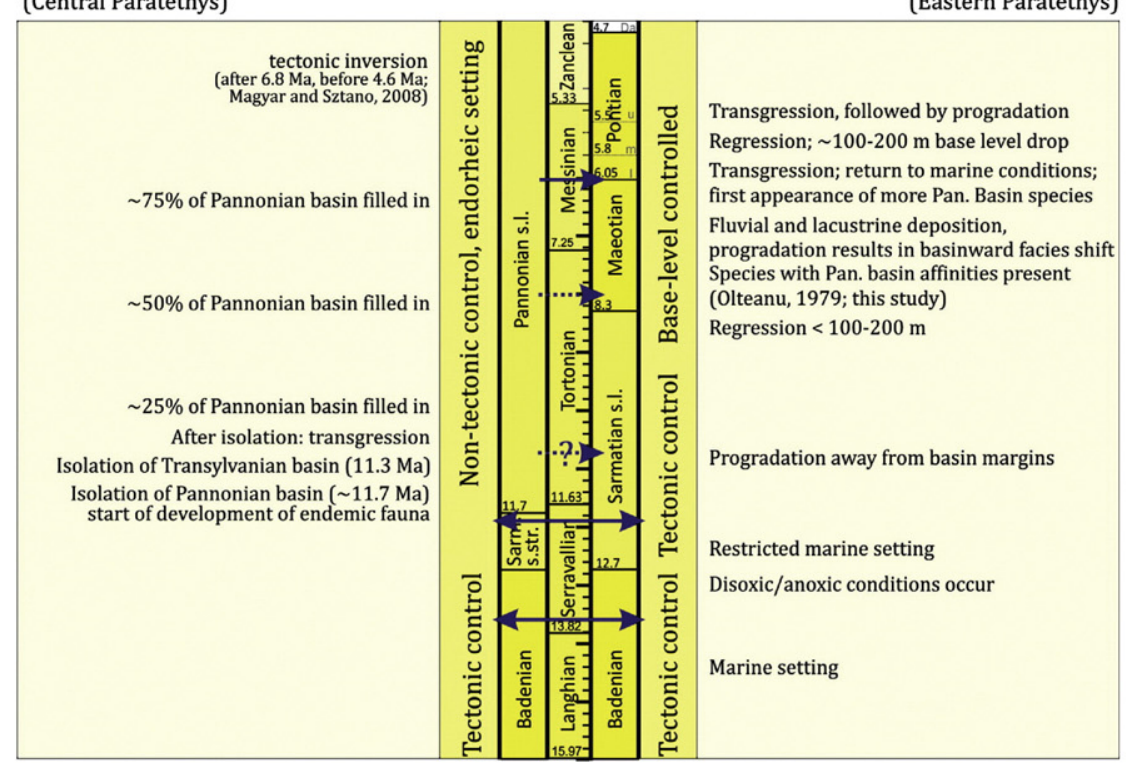

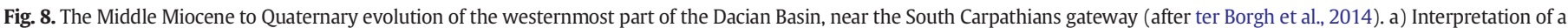

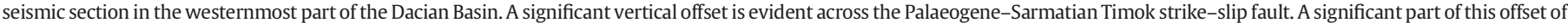

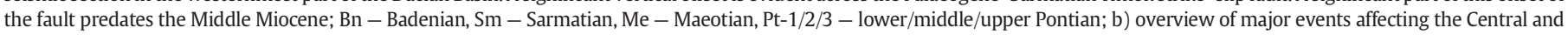
Eastern Paratethys during the Miocene and Pliocene, with specific regard to the connection between the Dacian and Pannonian basins.

In the SE Carpathians, one other mechanism is juxtaposed over the longer-term pattern of subsidence that has extreme values in the centre of the Focsani Basin ( $6 \mathrm{~km}$ of Upper Miocene-Quaternary sediments, Fig. 4). Large Pliocene-Quaternary differential vertical motions were recorded by $\sim 5 \mathrm{~km}$ of uplift of the external Carpathians nappes and up to $2 \mathrm{~km}$ of subsidence in the neighbouring Focsani Basin, which accommodated $\sim 5 \mathrm{~km}$ shortening (Leever et al., 2006; Matenco et al., 2007). This process is still highly active today: besides the well known intermediate mantle Vrancea earthquakes (Ismail-Zadeh et al., 2012 and references therein), there is a direct correlation between the crustal seismicity and the activity of recent faults derived from geophysical or neotectonic studies (Matenco et al., 2007), which has significant societal impact. For instance, the correlation of active faulting with the vertical movements derived from GPS studies resulted in predictions over the evolution in 

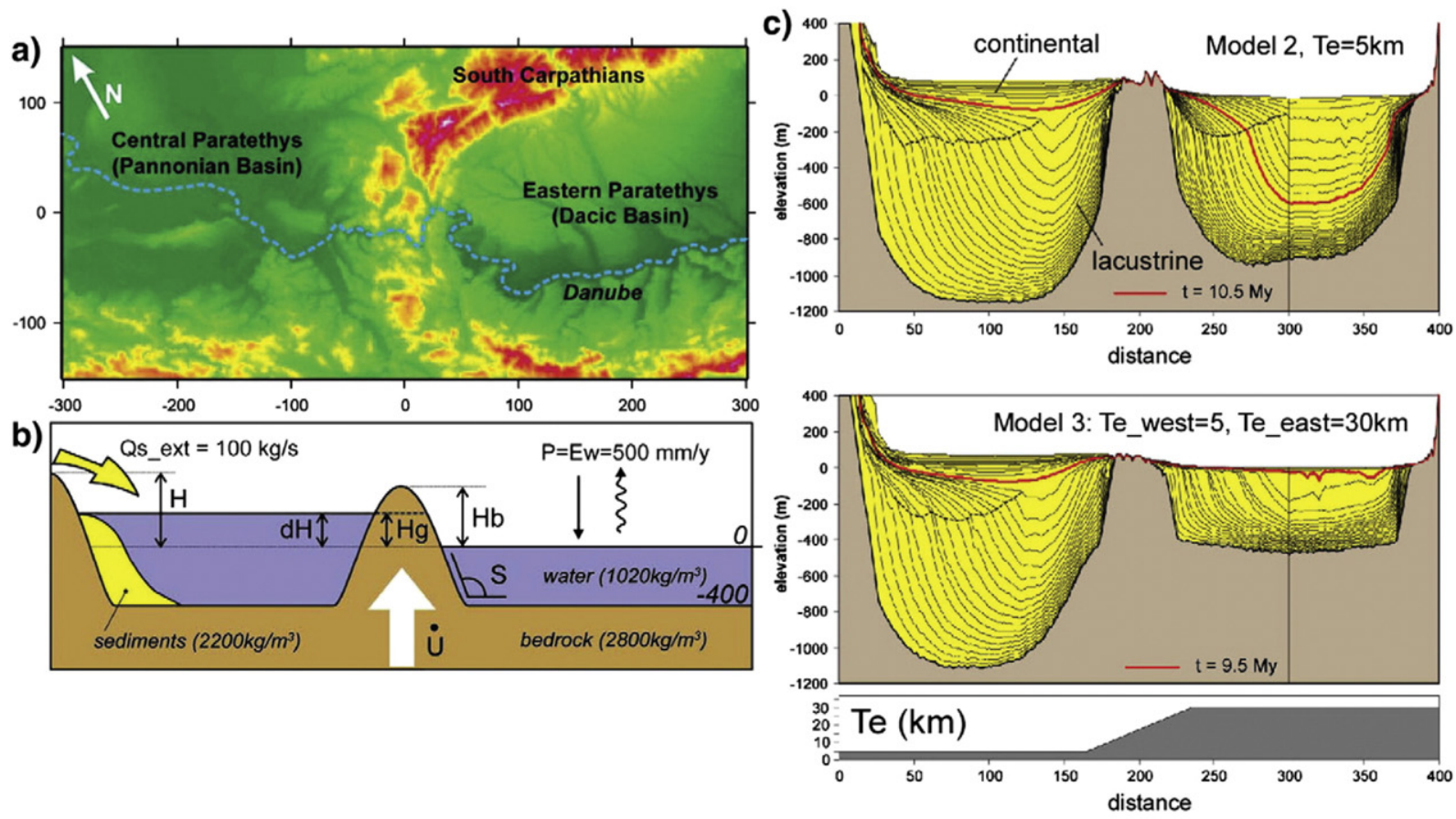

\begin{tabular}{|c|c|c|c|}
\hline & & \multicolumn{2}{|c|}{$\begin{array}{c}\text { small } \ll<\quad \text { elevation difference }(\mathbf{d H}) \quad \gg \text { large } \\
\text { between upstream and downstream water table at time of capture }\end{array}$} \\
\hline 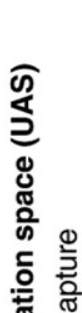 & & $\begin{array}{l}\text { Large UAS, small dH } \\
\quad \text { Limited effect on either of the basins } \\
\text { Upstream basin: lacustrine sedimentation } \\
\text { continues. Eventually, fluvial sedimentation } \\
\text { for weak lithosphere } \\
\text { Downstream basin: Time lag to bulk sedi- } \\
\text { mentation shift determined by upstream Te }\end{array}$ & $\begin{array}{l}\text { Large UAS, large dH } \\
\text { Upstream basin: capture-induced base level } \\
\text { fall causes erosion at basin margins, lacus- } \\
\text { trine sediments deposited in downstepping } \\
\text { geometry. Eventual fluvial sedimentation is } \\
\text { likely for weak lithosphere } \\
\text { Downstream basin: limited effect, time lag to } \\
\text { bulk sedimentation shift determined by } \\
\text { upstream Te }\end{array}$ \\
\hline 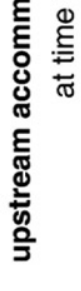 & $\frac{v}{\bar{V}}$ & $\begin{array}{l}\qquad \text { Small UAS, small dH } \\
\text { Upstream basin: some erosion, accelleration } \\
\text { of final basin filling. Fluvial sedimentation } \\
\text { unlikely } \\
\text { Downstream basin: increase in sedimenta- } \\
\text { tion rates immediate or after short time lag } \\
\text { (rate of change depending on Te) }\end{array}$ & $\begin{array}{l}\text { Small UAS, large dH } \\
\text { Large effect on both upstream and downstream basin } \\
\\
\text { Upstream basin: capture-induced base level } \\
\text { fall triggers final basin fill and extensive ero- } \\
\text { sion. Fluvial sedimentation highly unlikely } \\
\text { Downstream basin: immediate increase in } \\
\text { sedimentation rates upon capture (rate of } \\
\text { change depending on Te) }\end{array}$ \\
\hline
\end{tabular}

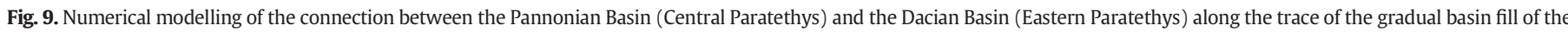

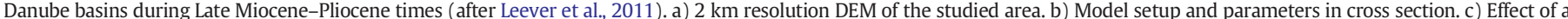

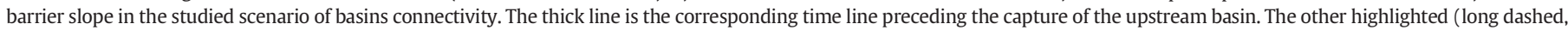

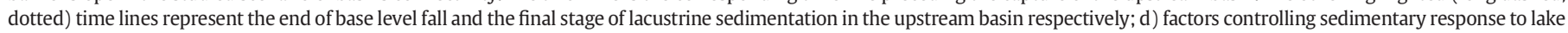
capture.

time of the area threatened by flooding in the foreland of the SE Carpathians (Fig. 10). This prediction infers a clear pattern of acceleration of flooding and rivers instability, in agreement with existing geomorphological studies (Rădoane et al., 2003).

\section{The combined Carpathians foreland - western Black Sea system}

One relevant example for the concept of time lag is the connected Dacian Basin-western Black Sea system during Miocene-Pliocene times. Numerous studies are available on the tectonic evolution and related sedimentation in both areas, but these were analysed individually
(Matenco and Andriessen, 2013 and references therein), lacking a coherent integration of both areas in terms of distribution of sediments relative to the dominant Carpatho-Balkanides source area.

\subsection{Connectivity between the Dacian Basin and the Black Sea}

The structural evolution and sedimentary architecture of the connected Dacian Basin-Black Sea system was analysed in the study of Munteanu et al. (2012). Using readily available information on the geometry, structure and kinematics of the Carpathians foreland (Leever et al., 2006; Matenco et al., 2007; Tărăpoancă et al., 2004) combined 

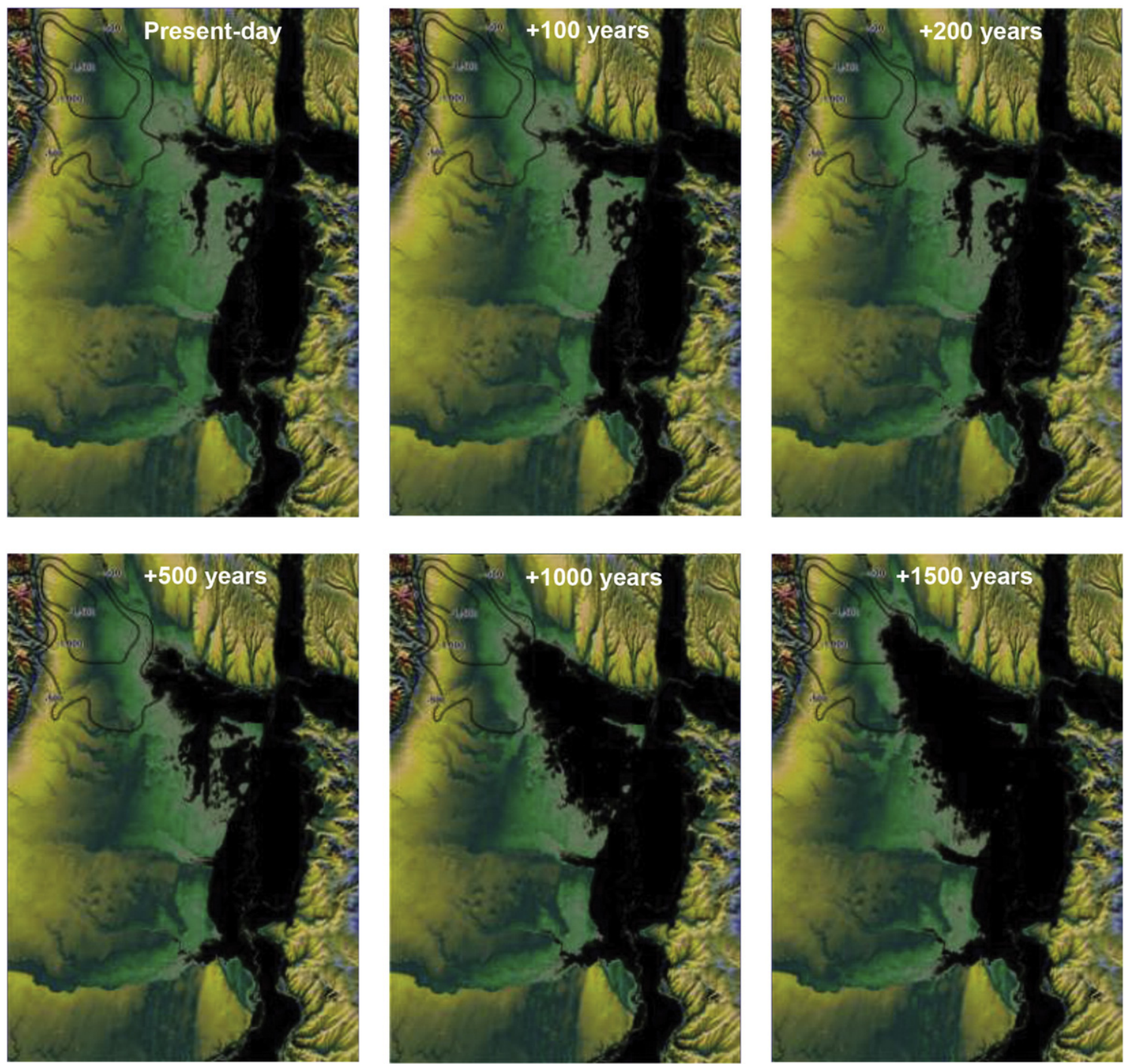

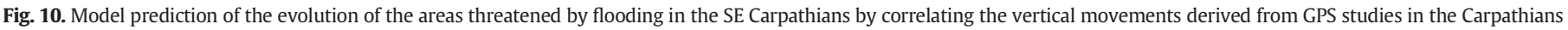
foreland (van der Hoeven et al., 2005) with active faulting patterns (see Matenco et al., 2007 for further details).

with a novel high resolution seismic stratigraphic interpretation in the western Black Sea, the study has quantified the moments and effects of connectivity between the two basins (Fig. 11). The analysis of a regional scale cross section (Fig. 2c) suggests that the Focsani Basin trapped sediments eroded from the Carpathians source area during Miocene-Quaternary times. One remarkable exception is observed when thick sedimentation associated with large-scale progradation features took place in the western Black Sea during the latest Miocene-earliest Pliocene (Meotian-Pontian, Fig. 11b,c). By comparison, lower thicknesses of sediments were deposited in the Dacian Basin. This geometry indicates that the accommodation space (i.e. the space available in the basin for sedimentation) decreased in the Dacian Basin. In this situation, the continued high rates of sedimentation fed by the Carpathians source areas shifted the sedimentation to the Black Sea. At the end of the latest Miocene-earliest Pliocene (Meotian-Pontian, Fig. 11b,c) period, the accommodation space increased in the Dacian Basin. This resulted in an increased capacity of this basin to capture the sedimentation fed at high rates by source areas and, therefore, the bulk of deposition shifted backwards to the Carpathians foreland. Large scale erosional features were observed in the entire Black Sea near the transition between the Miocene and Pliocene times, locally creating a spectacular paleo-relief depicted by the interpretation of seismic lines correlated with exploration wells (Dondurur et al., 2013; Gillet et al., 2007; Nikishin et al., 2015; Tari et al., 2009). This is obviously the result of sub-aerial erosion, the unconformity formed due to a regional sea-level drop of the Black Sea. Whether or not this unconformity fits at higher resolution the MSC timing and the amplitude of the sealevel drop is still a matter of debate. By quantifying coeval sedimentation change from erosion to mass-flows and turbiditic deposits in the deep-sea part of the Black Sea, the sequential stratigraphic analysis of Munteanu et al. (2012) has suggested that the sea-level drop was significant, possibly more than $1 \mathrm{~km}$ (Fig. 12). More relevant for our analysis, the study linked these Black Sea erosional features with a similar event in the Dacian Basin. It shows that large-scale sea level variations controlled the accommodation space in the system of two connected basins (Fig. 12c). Controlled by the height of the separating barrier, an outward sedimentation shift will occur from the trapping basin to the main sink (Fig. 12c). At 1.3-1.7 km sea-level drop and $200 \mathrm{~m}$ barrier height, the sedimentation shift will occur after $0.2 \mathrm{Ma}$, which is the time required for the accommodation space to be filled in the upstream Dacian Basin. An inward sedimentary shift will occur almost instantaneously, when the water level surpasses the barrier, and accommodation space is again created in the trapping basin (Fig. 12c). These observations demonstrate yet again the importance of sedimentation shifts in highresolution studies and the fact that erosional unconformities driven by regional mechanisms are diachronous across connected basins due to 

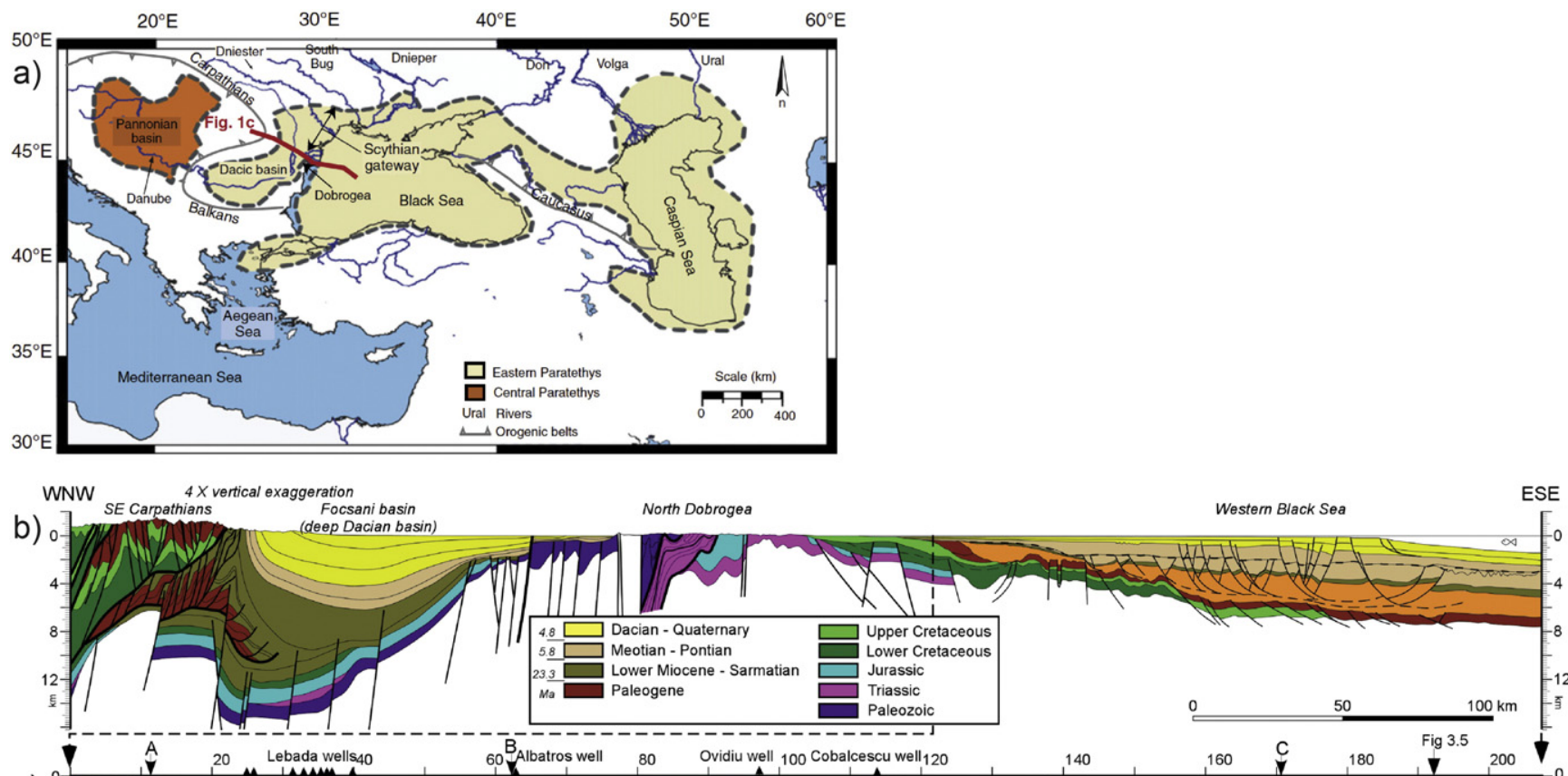

c)
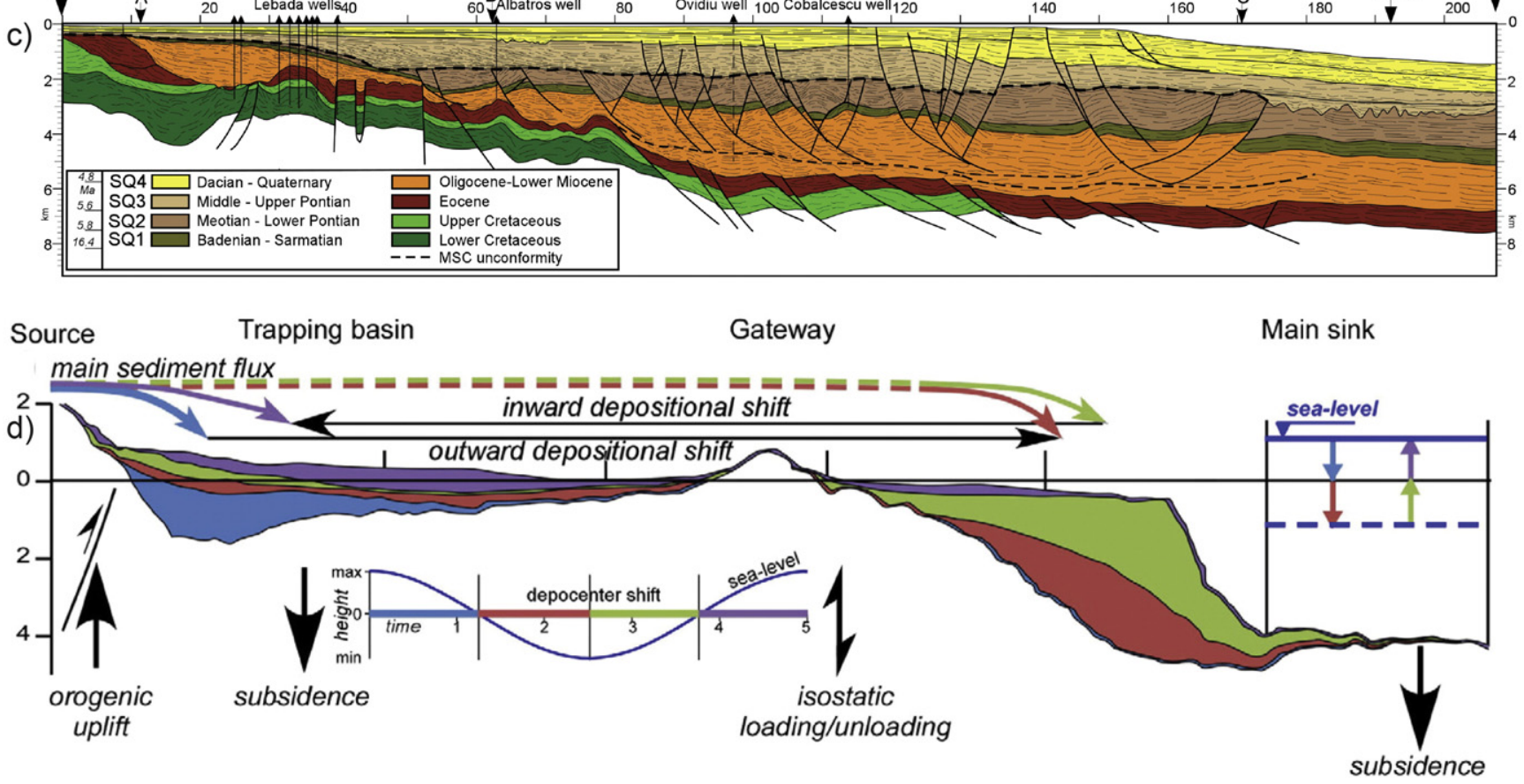

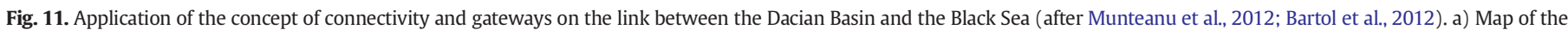

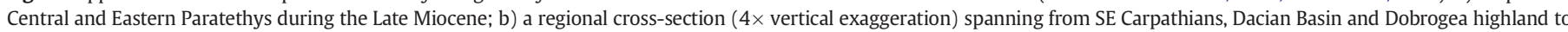

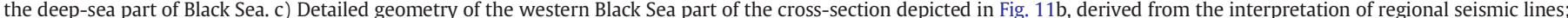

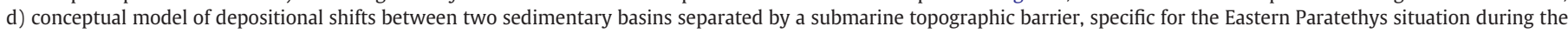

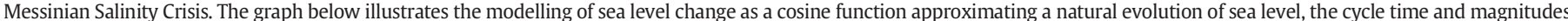

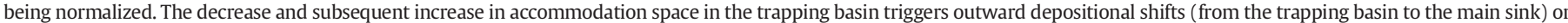
inward depositional shifts (from the main sink to the trapping basin), respectively.

the time required to fill available accommodation space. One other outcome is the demonstration that large-scale erosional features formed during large sea-level drops condition the subsequent distribution of deep-sea sedimentation. The mass- and turbiditic-type of transport, presently active in front of rivers discharging into the Black Sea is an inherited effect of the large sea-level drop recorded near the limit between Miocene and Pliocene times (Fig. 12b). These deep-sea turbiditic deposits were more sensitive to higher order sea-level variations than contemporaneous shelf sequences, thus capturing higher resolution changes in seismic data.
The concept of sedimentation shifts in the connected Dacian BasinBlack Sea system was analysed by numerical modelling in the study of Bartol et al. (2012) (Fig. 13). The model uses the same pseudo-3D numerical modelling code as the study of Leever et al. (2011) described above. The modelling setup simulates the Late Miocene-Pliocene connected Dacian Basin-western Black Sea system by allowing one source area feeding a trapping basin separated from the main sink by a submarine barrier (Fig. 13a,b). By assuming realistic erosion and sedimentation rates in a simplified setup of the natural scenario (Fig. 13a), the main parameters tested were the barrier height, amplitude of sea- 

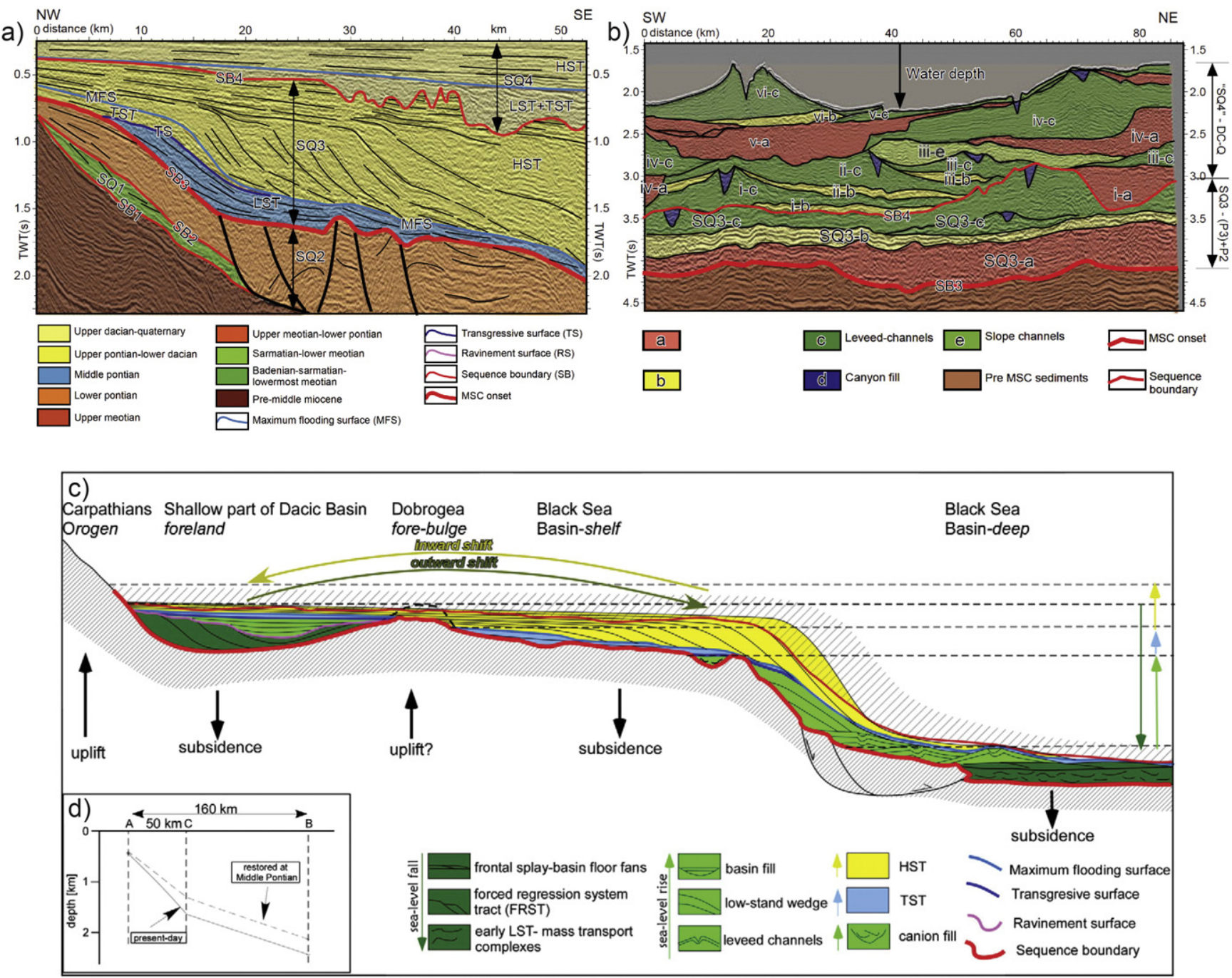

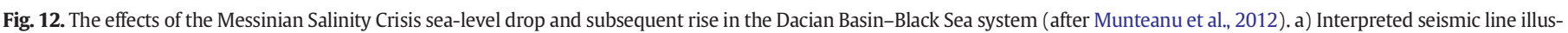

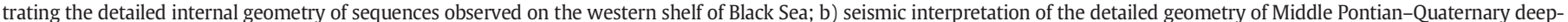

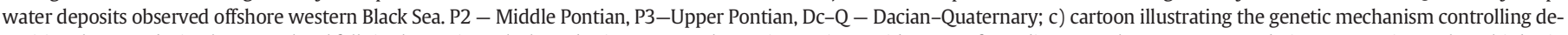

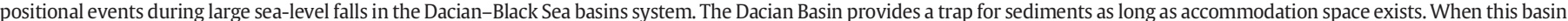

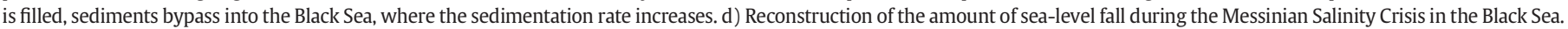

level variations, lithospheric strength and influence of climate. As a function of barrier height and cycle duration, the model predicts situations of no depositional shifts (no significant change in sedimentation rates), partial depositional shifts (change in sedimentation rates, but remains higher in the trapping basin) or full depositional shift (sedimentation rates are larger in the main sink between the shifts) (Fig. 13c). The occurrence of depositional shifts is controlled by the moment of sediment equilibration at the barrier, while the shift type is dependent on the time required to respond to the equilibration. In situations without a barrier, outward and inward depositional shifts occur when sea level falls below or rises above the floor of the trapping basin, cancelling or creating accommodation space. When a barrier is present, the outward depositional shift is delayed by the time required to reach sediment equilibration at the barrier. When the two situations are compared (i.e. without and with a barrier), this delay of a sediment shift onset is called timelag. In other words, the time lag means delaying the sedimentation shift and the main effects of the sea-level drop. Therefore, its understanding is crucial in deriving effects in connected basins. The time lag varies between 0.1-0.35 My for the studied natural scenario, increases with the duration of the sea-level cycle and with lower amplitudes of the sea-level drop, and it is not significantly influenced by barrier height (Fig. 13d). Modelling predicts that the time recorded by sub-aerial unconformities near the limit between Miocene and Pliocene should be in the order of 0.4-0.5 My in the Black Sea and the mountainous margin of the Dacian Basin, and 0.2-0.3 My in the centre of the trapping Dacian Basin. Given this timing and the observed full depositional shifts between the Dacian trapping basin and the main Black Sea sink, the numerical modelling predicts magnitudes of sea level drop larger than $1 \mathrm{~km}$, in agreement with earlier described inferences.

\subsection{Higher resolution studies in the western Black Sea}

The recent evolution of the Black Sea was influences by changes in external and internal forcing factors, comparable with the MiocenePliocene record of rapid changes in sedimentation patterns.

A significant number of high-resolution shallow seismic studies have been dedicated to the analysis of Quaternary sedimentation in the deep-water discharge fans located in front of main rivers in the western Black Sea (Fig. 14a, Dondurur et al., 2013; Lericolais et al., 2013; Lericolais et al., 2009; Popescu et al., 2004; Popescu et al., 2001). Following the start of this sedimentation type at the onset of Pliocene times, a large number of stratigraphic sequences were detected in these turbiditic fans at various orders of resolution. For instance, a correlation of high-resolution shallow seismic lines and facies observed in 


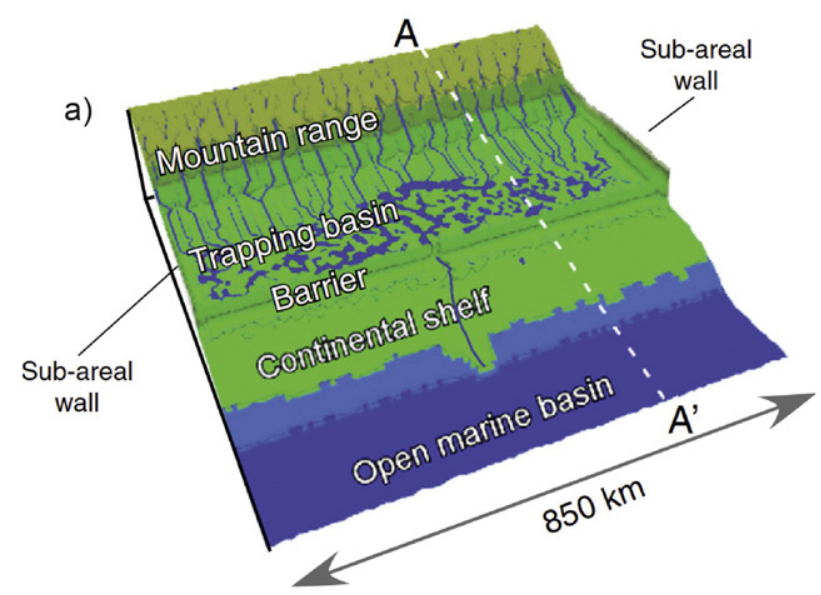

c)
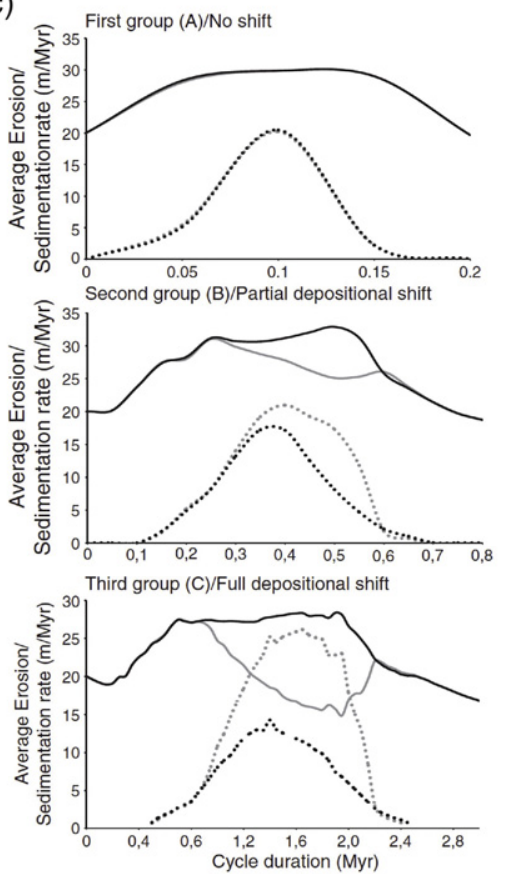

- Sedimentation in trapping basin ..... Erosion in open marine basin

- Erosion in trapping basin $\quad . .$. Sedimentation in open marine basin

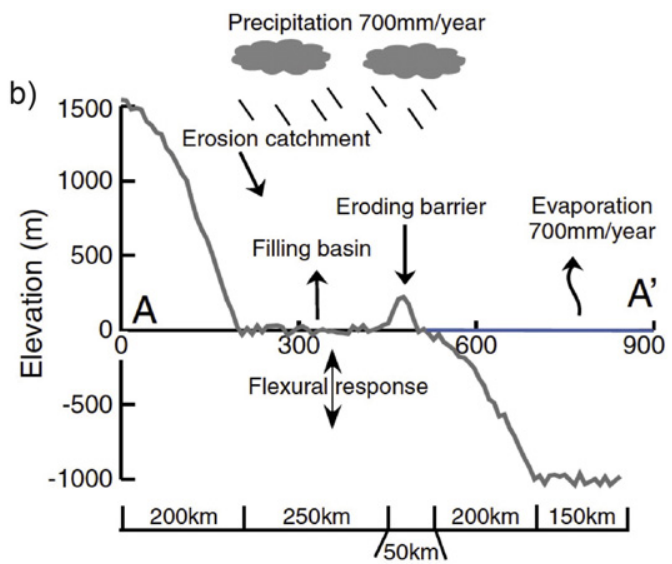

d)
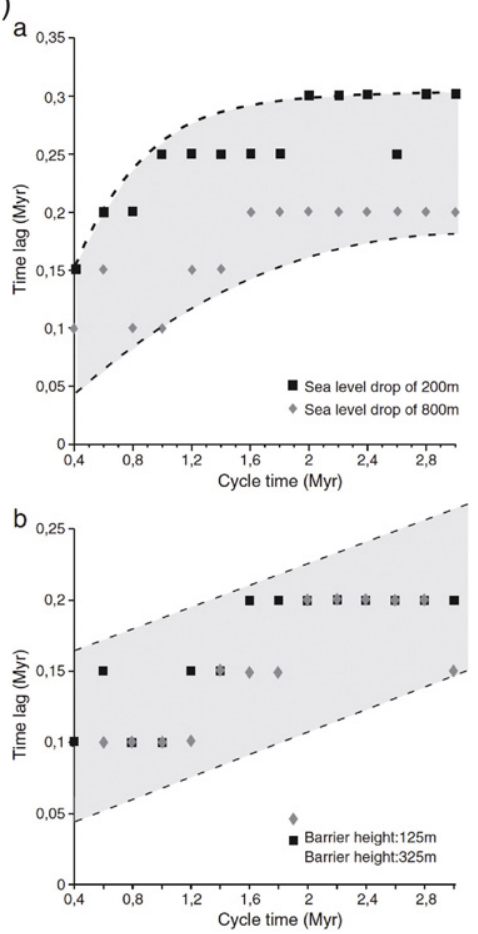

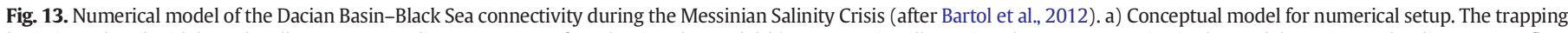

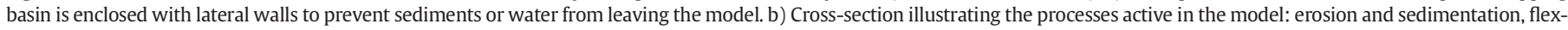

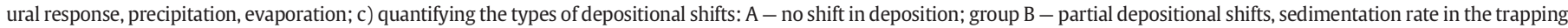

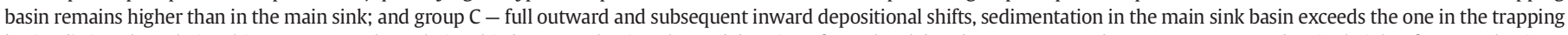

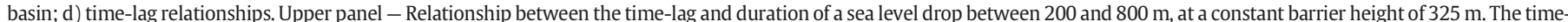

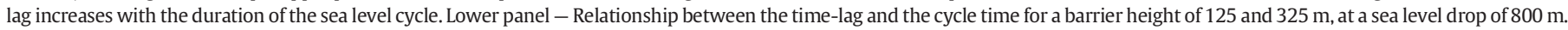
The time-lag does not appear to be dependent on the barrier height.

wells suggests a direct relationship between stratigraphic sequences and the cyclicity of the last glacial maximum and deglacial to more recent times (Fig. 14b).

The study of Lericolais et al. (2013) has inferred that the last glacial maximum deposits consist of thick mud turbidites overlain by the lobe deposits of the Danube deep-sea fan (Fig. 14a,b). Sediments supplied by the Danube bypassed the shelf to the deep sea through the deeply incised Viteaz canyon. This deep sea progradation is linked with a change in the sediment supply of the Danube River combined with deposition directly in the deep sea, when sea-level was close to the position of the shelf break. At high stands, this type of construction records only condensed pelagic sedimentation. Overlying these deposits, the deposition of thick turbidites in the Danube deep-sea fan associated with reworked red continental clays suggests mixing with another source located more to the south during deglacial times ( 18-15.5 Ka BP). A period of carbonate rich deposition was possibly linked with a period of reversing water balance and sea-level drop to $\sim 100 \mathrm{~m}$ or lower below the present day position, following the meltwater driven high-stand. This was followed by the reconnection with the marine realm and the onset of deposition of sapropel deposits in the deeper parts of the Black Sea, correlated with a major change in magnetic minerals to greigite in particular at the lacustrine/marine transition (Major et al., 2006; Strechie et al., 2002). Interestingly, the oldest date of $7.4 \mathrm{Ka} \mathrm{BP}$ of the first sapropel deposit does not coincide with the onset of marine incursion from the Mediterranean across the Bosphorus strait, which is dated at $~ 9$ Ka BP (Nicholas et al., 2011; Soulet et al., 2011). But it coincides with the time when the salinity rose to the sufficient level required for the depletion of bottom water oxygen and sapropel deposition. The delay between the onset of marine incursion and the first sapropel deposition of $\sim 1.6 \mathrm{Ka}$ is a geochemical time lag. It infers that connectivity events are not coeval with the onset of expected geochemical conditions of sedimentation. This time 
a)
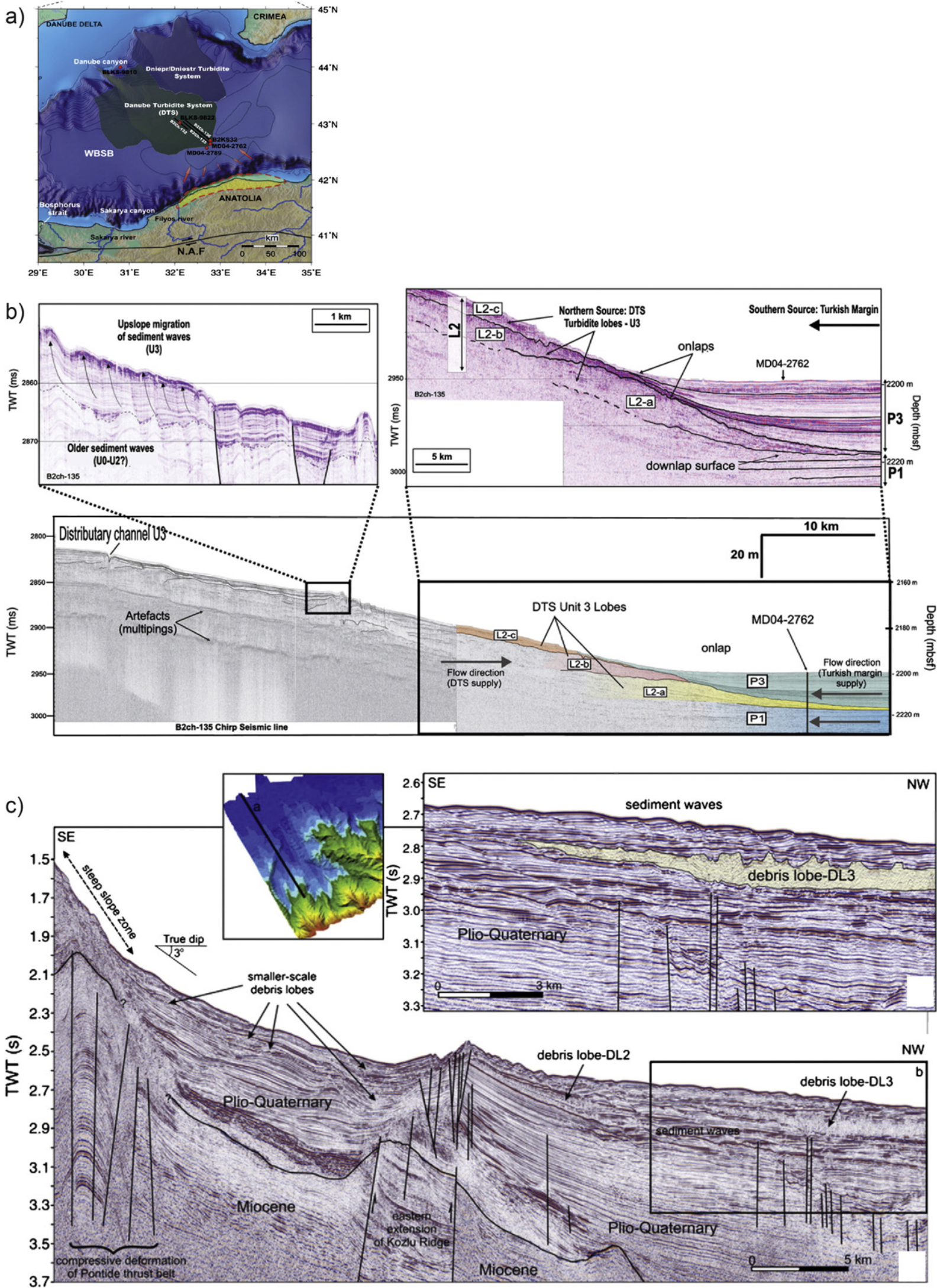

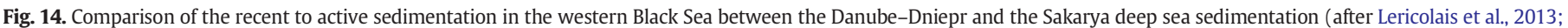

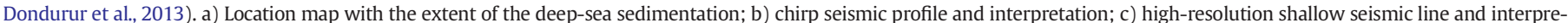

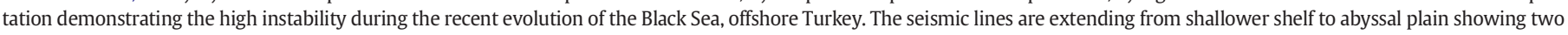
buried large debris flow lobes DL2 and DL3. The upper panel is a close-up and interpretation of the DL3 debris lobe. 
lag is of different type when compared with the one earlier discussed on sedimentation shifts and takes place at different time scales.

The other major source of sediment supply in the western Black Sea system is the drainage system of the western Pontides along its northern fluvial system, such as Sakarya and neighbouring rivers (Fig. 14a). Their influx has been analysed in the study of Dondurur et al. (2013) (Fig. 14c). The rapid environmental changes coupled with the active tectonics occurring in the Pontides have resulted in significant sedimentological variations and a high level of instability of the sedimentary wedge deposited in the passive continental margin and the deep sea. By analysing a number of high quality shallow seismic profiles combined with multi-beam bathymetry and chirp seismic data, the study has demonstrated the high instability of the southern margin of western Black Sea. This is characterized by significant sediment erosion associated with major slides and buried debris lobes in the offshore (Fig. 14c). The sliding includes failures in the steep slope zones, smaller slides on the canyon walls, and relatively larger slides in the mass failure zone. Toe-slope decollements were possibly triggered by local seismic activity. A number of large debris lobes were buried in Quaternary sediments, formed by excess pore pressures due to high sediment input and submarine fluid flow. The active tectonics triggered the sliding, facilitated by excess pore pressures in shallow sediments due to the submarine fluid flow possibly produced by gas hydrate dissociation. The latter is most probably the result of the penetration in the Black Sea of warmer Mediterranean water during the rapid transgression after the Last Glacial Maximum.

\section{Inferences on the interplay between long-term natural processes and recent/anthropogenic changes in the Danube-Black Sea system}

Our review demonstrates that vertical movements recorded by the Carpathian Mountains have driven not only the formation and evolution of the associated basins but also their subsequent fill along roughly the present trace of the Danube River. The least controlled connectivity event is the Middle Miocene (Badenian) onset of marine conditions in the Pannonian and Transylvanian basins, when these became connected with the Carpathians foreland (e.g., Rögl, 1999 and references therein). Thermochronology demonstrates that the West, East and SE Carpathians were already affected by regional tectonic exhumation since Oligocene times. We cannot exclude the existence of individual corridors, but such possible type of sedimentation connecting basins is missing or was removed by subsequent erosion. Thermochronology indicates that the first order topographic patterns of the South Carpathians were established already during Cretaceous-Paleogene times (Merten, 2011). The few overprinting Miocene ages are focussed mainly in the western area of the South Carpathians adjacent to the Pannonian Basin and infer a period of pre-dating burial and coeval exhumation. The former took place in response to Eocene orogen parallel extension and large-scale transtensional movements accommodating the onset of tectonic invasion into the Carpathian embayment. This extensional subsidence ultimately created a connection in the South Carpathians area between the Central and Eastern Paratethys. The subsequent severing of this connection during Late Miocene times at 11.7-11.3 Ma (ter Borgh, 2013; ter Borgh et al., 2013) and the formation of the endemic Pannonian lake (Magyar et al., 1999) took place by tectonic uplift of the same South Carpathians, but this uplift was restricted to $\sim 2-5 \mathrm{~km}$ in such a way that the first order Cretaceous-Paleogene topography pattern was still preserved.

One other interesting process took place during the transition between the Miocene and Pliocene at the time of sedimentation shifts between the Dacian Basin and the Black Sea. In most of Dacian Basin a clear sea-level drop associated with an erosional unconformity in proximal areas is observed. Such regional unconformity is not obvious in the rapidly subsiding Focsani Basin. The sea-level drop has been detected in its proximal parts, but seismic interpretation studies were not able to detect an erosional unconformity in the basin (Matenco et al., 2007; Stoica et al., 2013) that was associated with cancelling the accommodation space and shifting the sediments to the Black Sea. This is because the rapid subsidence kept the continental base level (the point of transition between continental erosion and deposition) at higher topographic elevations than the present remainder of the Focsani Basin, highly eroded on its NW flank by the Quaternary uplift of the SE Carpathians (Fig. 4, Leever et al., 2006). This mechanism is compatible with the recent situation: although thick alluvial sediments are still being deposited in the Focsani Basin, the bulk of sediments bypasses this basin and is transported by the Danube River into the Black Sea (Fig. 8). The same situation took place in the SE part of the Pannonian Basin during the deposition of thick Pliocene-Quaternary alluvial sediments that presently continues (Fig. 4, Juhasz et al., 2007; ter Borgh et al., 2015). A marked erosional unconformity is missing in both Pannonian and Focsani basins, although the bulk of Danube sediments have bypassed them on their way to the Black Sea. These observations demonstrate that simple stratigraphic observations are unable to quantify connectivity moments, which requires high-resolution sequence stratigraphy coupled with exhumation and landform evolution studies over the gateways separating sedimentary basins.

These long-term natural processes interact with present-day anthropogenic changes. The marked loss of longitudinal and lateral continuity along the Danube and its tributaries due to hydroelectric dams and flood protection works (Habersack et al., 2015) interact with the natural long-term tendencies of vertical motions associated with erosion, sedimentation and connectivity along its various sections. The most obvious situation is in the area of the SE Carpathians, its neighbouring Focsani Basin and surrounding subsiding areas including the $\mathrm{N}-\mathrm{S}$ oriented Danube segment before its entrance into the Danube Delta (Fig. 3). The rapid subsidence of up to $7 \mathrm{~mm} /$ year of the centre of the Focsani Basin coupled with the $2-3 \mathrm{~mm} /$ year uplift of the SE Carpathians (van der Hoeven et al., 2005) induces a marked nonequilibrium of the SE Carpathians rivers. This is observed both in the longitudinal profiles, sediments accumulated by existing dams and a marked increase in natural hazards such as landsliding (Bălteanu et al., 2010; Rădoane and Rădoane, 2005; Rădoane et al., 2003). The East Carpathians hydroelectric works shifted upstream and multiplied continental base levels (equilibrium between erosion and sedimentation), leaving starved the area capturing the highest relative production of sediments across the entire Romanian segment of the Carpathians foreland, i.e. the Focsani Basin. Such starvation multiplies the active sedimentation tendency of the natural system that will equilibrate by gradually enhancing the flooding, landsliding and torrential production of sediments in the basin (e.g., Micu and Bălteanu, 2013). Furthermore, deforestation actively taking place in this area enhances the transport of sediments (e.g., Romanescu and Nistor, 2011). In such a natural system, renewed traditional engineering measures of protection will only enhance the magnitude of these events. At the same time, these anthropogenic works have interrupted the bypass of Carpathians sediments flux over the Focsani Basin towards the Black Sea. The response of the natural system is to capture, at human scale (Fig. 10), the remaining flux of sediments in the Focsani Basin, i.e. the one of the Danube, enhanced by the differential subsidence in respect to the Dobrogea high. This is observed at present by a gradual migration of sedimentary and water budget from the eastern, navigable Danube branches to the western ones (Constantinescu et al., 2015; Denk et al., 2010; Nedea et al., 2012). The same situation is observed in the eastern part of the Pannonian basin, where the flux of sediments of the Danube and Tisza rivers are affected by hydroelectric works and, in the same time, by large scale flooding events (Habersack et al., 2015; Timar et al., 2005). The system is affected by sediment starvation and will increase the magnitude of such events in the centre of the Great Hungarian Plain.

The Miocene-Quaternary evolution of sedimentary basins presently filled and aligned along the middle and lower traces of the Danube River system (Pannonian/Transylvania and Dacian) together with the sedimentary evolution of the western Black Sea are the result of rapid tectonic changes of the Carpathians Mountains. These changes are still 
driving presently the transfer of sediments towards the main Black Sea sink. The spatial and temporal scales of these processes are contrastingly different in the entire system. Long-term tectonic processes (in the order of $10^{6} \mathrm{My}$ ) drive the formation and evolution of the main basins, such as back-arc extension of the Pannonian Basin, sag subsidence of the Transylvanian Basin, flexural subsidence of the Carpathians foreland or inversion of the western Black Sea. Threshold conditions demonstrate that basin separation or connectivity events take place in spatially restricted areas with one order of magnitude faster rates (in the order of $10^{4}-10^{5} \mathrm{My}$ ) than background tectonic processes. Relevant examples include the connectivity across the South Carpathians or in between the Dacian Basin and the western Black Sea. Locally, some tectonic or sedimentological processes may accelerate and encompass the scale of connectivity events, such as the $\sim 70 \mathrm{~km} /$ My deltaic slope advance in the shallow Pannonian lake or the $2.5 \mathrm{~km} /$ My Quaternary exhumation rate in the SE Carpathians. Connectivity processes associated with geochemical or environmental changes act in an even narrower depth interval (tens of metres) and at higher temporal resolution (in the order of $10^{3}-10^{4} \mathrm{My}$ ). Relevant examples include environmental changes induced by the recent opening of the Black Sea gateways towards the Mediterranean or the rapid geochemical changes that were inferred for the Miocene connectivity events of the Mediterranean and Paratethys (e.g., Karami et al., 2011).

Such rapid connectivity processes at spatially restricted gateways are enhanced by anthropogenic changes. The most relevant example is the restriction in terms of sediments flux created by the hydroelectric dams in the South Carpathians Iron Gates gateway. The natural situation is one where the Pannonian and Dacian basins were connected in the same sediment transport system, with rapid rivers captures and knickpoints migration in late Quaternary at the exit of the Danube in the Dacian Basin (ter Borgh, 2013). The dams have created an artificial sediment barrier, and therefore created individual continental base levels in the Pannonian and Dacian basins by separation in the same area where the Miocene barrier existed. Our study of these Miocene barriers demonstrate that the natural response of the new dams will be enhanced sedimentation in the SE Pannonian basin, enhanced erosion downstream these dams in the Dacian basin and shifting the sedimentation area more to the Focsani Basin. These inferences are in agreement with observations, in particular relevant because artificial levees resulted in major floods occurring by natural failure through water channelling (Constantinescu et al., 2015; Habersack et al., 2015). Although similar effects are observed in general to any dam, the situation in the Iron Gates is highly enhanced by the juxtaposition over an inherited gateway between basins and by the active uplift of the South Carpathians.

Similar processes take place also at the Danube Delta gateway between the Dacian Basin and the Black Sea, although the anthropogenic impact is far more complex that possible quantifications from our study of geological sediment budget. Stopping the Carpathians sedimentation in the Focsani Basin and bypass towards the Black Sea, together with eventual capturing of Danube sediments in the Focsani Basin enhance the coarse sediment starvation in the Danube Delta and the neighbouring Black Sea, already affected by a complex alteration of the export of fluvial materials causing rapid changes in morphology, chemistry and bio-facies (Giosan et al., 2012 and references therein). This is increasing the Black Sea shelf sediment bypass towards the deep-sea, already enhanced by the gradual salinity decrease during the Late Holocene (Lericolais et al., 2013; Popescu et al., 2004; van der Meer et al., 2008), resulting in the observed widespread coastal erosion (Stănică et al., 2011; Stănică and Panin, 2009).

\section{Conclusions}

Worldwide observations indicate numerous such situations of (sub-)basins affected by moments of isolation and connectivity that interact with recent or anthropogenic changes. Such situations are generally not well quantified, nor properly understood. The DanubeBlack Sea system in the framework of the larger Paratethys can serve as a good example, whose mechanics and processes can certainly be ported elsewhere. Situations of basin isolation followed by connectivity and sedimentation shifts are rather common during orogenic evolution, in particular when its late stages are driven by slab retreat, a process that is still active in many worldwide orogens. The simple Miocene translation of Carpathians continental units collapsing by extension the back-arc and shortening the foreland followed by rapid infill is not unique. Most other highly curved Mediterranean orogens show similar evolutions. Examples include the $\mathrm{W}$-ward movement of the Betics-Rif system and coeval extensional collapse of the Alboran Domain in the Western Mediterranean and its onshore Miocene basins, driven by the roll-back of the Gibraltar slab (Vergés and Fernàndez, 2012). This rapid roll-back was intimately related with the isolation and subsequent re-connection of the Mediterranean with the Atlantic over the Gibraltar gateway during and after the Mediterranean MSC. Similar multiple basins opening events took place during the $\mathrm{W}$-ward movement of the Calabrian slab accommodated by Oligocene-Quaternary shortening at the exterior of the Apennines and coeval back-arc extension of the oceanic Liguro-Provencal and Tyrrhenian basins (Faccenna et al., 2014). One much larger example is the $\sim 900 \mathrm{~km}$ of S-ward translation of Aegean units that was accompanied by $\sim 500 \mathrm{~km} \mathrm{~N}-\mathrm{S}$ EuropeAfrica convergence, while the amount of subducted material in the mantle is in the order of $1500 \mathrm{~km}$ (Jolivet and Brun, 2010). One other example is the gradual opening of the SE China Sea and its multiple moments of inversion and closure that still take place today (Pubellier and Morley, 2014).

The analysis of the Danube River-Black Sea system demonstrates that understanding basin evolution and parameters driving changes across basins in such a staggering range of spatial and temporal scales affected by recent anthropogenic changes is very challenging, to say the least. The solution lies in controlling a wide range of parameters, from the tectonic and sedimentological background, threshold conditions to geochemical changes, which obviously implies collaboration inside a wide range of disciplines. Understanding the genesis and natural evolution of the Danube River-Black Sea region during longer geological times represents the foundation on which the human interventions on the system can be better estimated. If well understood, such natural evolution during geological times gives the solution to the most important integrated management question - to intervene or to adapt.

\section{Acknowledgements}

This review is based on the long-term commitment of The Netherlands Research Centre for Integrated Solid Earth Science (ISES) to understand the kinematics and exhumation of the Carpathians as well as the evolution of neighbouring Paratethys basins. We acknowledge the research of the FP7 DANCERS project (EC Grant Agreement no. 603805) that has provided key insights for this study. Paul Andriessen and Sierd Cloetingh are acknowledged for their long-term collaboration. Two anonymous reviewers are gratefully acknowledged for their suggestions that have significantly improved an earlier manuscript.

\section{References}

Bada, G., Horváth, F., Dövényi, P., Szafián, P., Windhoffer, G., Cloetingh, S., 2007. Presentday stress field and tectonic inversion in the Pannonian basin. Glob. Planet. Chang. 58, 165-180.

Bălteanu, D., Chendes, V., Sima, M. Enciu, P., 2010. A country-wide spatial assessment of landslide susceptibility in Romania. Geomorphology 124, 102-112.

Bartol, J., Matenco, L., Garcia-Castellanos, D., Leever, K., 2012. Modelling depositional shifts between sedimentary basins: sediment pathways in Paratethys basins during the Messinian salinity crisis. Tectonophysics 536-537, 110-121.

Bocin, A., Stephenson, R., Tryggvason, A., Panea, I., Mocanu, V., Hauser, F., Matenco, L., 2005. 2.5D seismic velocity modelling in the south-eastern Romanian Carpathians Orogen and its foreland. Tectonophysics 410, 273-291. 
Bojar, A.V., Neubauer, F., Fritz, H., 1998. Jurassic to Cenozoic thermal evolution of the southwestern South Carpathians: evidence from fission-track thermochronology. Tectonophysics 297, 229-249.

Burchfiel, B.C., Nakov, R., Dumurdzanov, N., Papanikolaou, D., Tzankov, T., Serafimowski, T., King, R.W., Kotzev, V., Todosov, A., Nurce, B., 2008. Evolution and dynamics of the Cenozoic tectonics of the south Balkan extensional system. Geosphere 4, 919-938. http://dx.doi.org/10.1130/GES00169.1.

Cloetingh, S., Bada, G., Matenco, L., Lankreijer, A., Horvath, F., Dinu, C., 2006. Modes of basin (de)formation, lithospheric strength and vertical motions in the PannonianCarpathian system: inferences from thermo-mechanical modelling. Geol. Soc. Lond. Mem. 32, 207-221.

Cloetingh, S., Matenco, L., Bada, G., Dinu, C., Mocanu, V., 2005. The evolution of the Carpathians-Pannonian system: interaction between neotectonics, deep structure, polyphase orogeny and sedimentary basins in a source to sink natural laboratory. Tectonophysics 410, 1-14.

Cloetingh, S.A.P.L., Burov, E., Matenco, L., Toussaint, G., Bertotti, G., Andriessen, P.A.M., Wortel, M.J.R., Spakman, W., 2004. Thermo-mechanical controls on the mode of continental collision in the SE Carpathians (Romania). Earth Planet. Sci. Lett. 218, 57-76.

Constantinescu, S., Achim, D., Rus, I., Giosan, L., 2015. Embanking the lower danube: from natural to engineered floodplains and back. In: Hudson, P.F., Middelkoop, H. (Eds.), Geomorphic Approaches to Integrated Floodplain Management of Lowland Fluvial Systems in North America and Europe. Springer, New York, pp. 265-288.

Danisik, M., Kohut, M., Evans, N.J., McDonald, B.J., 2012. Eo-Alpine metamorphism and the 'mid-Miocene thermal event' in the Western Carpathians (Slovakia): new evidence from multiple thermochronology. Geol. Mag. 149, 158-171.

de Leeuw, A., Bukowski, K., Krijgsman, W., Kuiper, K.F., 2010. Age of the Badenian salinity crisis; impact of Miocene climate variability on the circum-Mediterranean region. Geology 38, 715-718.

Denk, I., Simoner, M., Steiner, F., Kikinger, P., Marktl, P., 2010. Network of Danube Waterway Administrations: Status Quo Report on Waterway Maintenance. NEWADA South East Europe transnational cooperation programme, Vienna, Austria 24 pp.

Dimitrijević, M.D., 1997. Geology of Yugoslavia. 2nd edition. Geoinstitute, Belgrade, Belgrade.

Dinu, C., Wong, H.K., Tambrea, D., Matenco, L., 2005. Stratigraphic and structural characteristics of the Romanian Black Sea shelf. Tectonophysics 410, 417-435.

Doglioni, C., Carminati, E., Cuffaro, M., Scrocca, D., 2007. Subduction kinematics and dynamic constraints. Earth Sci. Rev. 83, 125-175.

Dombrádi, E., Timár, G., Bada, G., Cloetingh, S., Horváth, F., 2007. Fractal dimension estimations of drainage network in the Carpathian-Pannonian system. Glob. Planet. Chang. 58, 197-213.

Dondurur, D., Küçük, H.M., Çifçi, G., 2013. Quaternary mass wasting on the western Black Sea margin, offshore of Amasra. Glob. Planet. Chang. 103, 248-260.

Ellouz, N., Roure, F., Săndulescu, M., Bădescu, D., 1994. Balanced cross sections in the eastern Carpathians (Romania): a tool to quantify Neogene dynamics. In: Roure, F. Ellouz, N., Shein, V.S., Skvortsov, I. (Eds.), Geodynamic evolution of sedimentary basins, International Symposium Moskow 1992 Proceedings. Technip, Paris, pp. 305-325.

Faccenna, C., Becker, T.W., Miller, M.S., Serpelloni, E., Willett, S.D., 2014. Isostasy, dynamic topography, and the elevation of the Apennines of Italy. Earth Planet. Sci. Lett. 407, 163-174.

Faccenna, C., Piromallo, C., Crespo-Blanc, A., Jolivet, L., Rosetti, F., 2004. Lateral slab deformation and the origin of the western Mediterranean arcs. Tectonics 23, TC1012. http://dx.doi.org/10.1029/2002TC001488.

Fügenschuh, B., Schmid, S.M., 2005. Age and significance of core complex formation in a very curved orogen: evidence from fission track studies in the South Carpathians (Romania). Tectonophysics 404, 33-53.

Gallhofer, D., von Quadt, A., Peytcheva, I., Schmid, S.M., Heinrich, C.A., 2015. Tectonic magmatic, and metallogenic evolution of the Late Cretaceous arc in the CarpathianBalkan orogen. Tectonics 34. http://dx.doi.org/10.1002/2015TC003834.

Garcia-Castellanos, D., 2002. Interplay between lithospheric flexure and river transport in foreland basins. Basin Res. 14, 89-104.

Gillet, H., Lericolais, G., Rehault, J.-P., 2007. Messinian event in the black sea: evidence of a Messinian erosional surface. Mar. Geol. 244, 142-165.

Giosan, L., Coolen, M.J.L., Kaplan, J.O., Constantinescu, S., Filip, F., Filipova-Marinova, M. Kettner, A.J., Thom, N., 2012. Early anthropogenic transformation of the DanubeBlack Sea System. Sci. Rep. 2, 582.

Govers, R., Wortel, M.J.R., 2005. Lithospheric tearing at STEP faults: response to edges of subduction zones. Earth Planet. Sci. Lett. 236, 505-523.

Graham, R., Kaymakci, N., Horn, B.W., 2013. Revealing the mysteries of the Black Sea. GEO ExPro 10, 58-62.

Habersack, H., Hein, T., Stanica, A., Liska, I., Mair, R., Jäger, E., Hauer, C., Bradley, C., 2016 Challenges of river basin management: current status of, and prospects for, the River Danube from a river engineering perspective. Sci. Total Environ. 543, 828-845 (this volume).

Hiscott, R.N., Aksu, A.E., Mudie, P.J., Marret, F., Abrajano, T., Kaminski, M.A., Evans, J., Çakiroglu, A.I., Yasar, D., 2007. A gradual drowning of the southwestern Black Sea shelf: evidence for a progressive rather than abrupt Holocene reconnection with the eastern Mediterranean Sea through the Marmara Sea Gateway. Quat. Int. 167-168, 19-34.

Horváth, F., Bada, G., Szafian, P., Tari, G., Adam, A., Cloetingh, S., 2006. Formation and deformation of the Pannonian Basin: constraints from observational data. Geol. Soc. Lond. Mem. 32, 191-206.

Ismail-Zadeh, A., Matenco, L., Radulian, M., Cloetingh, S., Panza, G., 2012. Geodynamics and intermediate-depth seismicity in Vrancea (the south-eastern Carpathians): current state-of-the art. Tectonophysics 530-531, 50-79.

Ivanov, Z., 1988. Apercu general sur l'evolution geologique et structurale du massif des Rhodopes dans le cadre des Balkanides. Bull. Soc. Geol. Fr. IV, 227-240.
Jipa, D.C., Olariu, C., 2013. Sediment routing in a semi-enclosed epicontinental sea: Dacian Basin, Paratethys domain, Late Neogene, Romania. Glob. Planet. Chang. 103, 193-206

Jolivet, L., Augier, R., Robin, C., Suc, J.-P., Rouchy, J.M., 2006. Lithospheric-scale geodynamic context of the Messinian salinity crisis. Sediment. Geol. 188-189, 9-33.

Jolivet, L., Brun, J.-P., 2010. Cenozoic geodynamic evolution of the Aegean. Int. J. Earth Sci. 99, 109-138.

Juhasz, G., Pogacsas, G., Magyar, I., Vakarcs, G., 2007. Tectonic versus climatic control on the evolution of fluvio-deltaic systems in a lake basin, Eastern Pannonian Basin. Sediment. Geol. 202, 72-95.

Karami, M.P., de Leeuw, A., Krijgsman, W., Meijer, P.T., Wortel, M.J.R., 2011. The role of gateways in the evolution of temperature and salinity of semi-enclosed basins: an oceanic box model for the Miocene Mediterranean Sea and Paratethys. Glob. Planet Chang. 79, 73-88.

Kreemer, C., Holt, W.E., Haines, A.J., 2003. An integrated global model of present-day plate motions and plate boundary deformation. Geophys. J. Int. 154, 8-34.

Krézsek, C., Bally, A.W., 2006. The Transylvanian Basin (Romania) and its relation to the Carpathian fold and thrust belt: insights in gravitational salt tectonics. Mar. Pet. Geol. 23, 405-442.

Krézsek, C., Filipescu, S., 2005. Middle to late Miocene sequence stratigraphy of the Transylvanian Basin (Romania). Tectonophysics 410, 437-463.

Krézsek, C., Filipescu, S., Silye, L., Matenco, L., Doust, H., 2010. Miocene facies association and sedimentary evolution of the Southern Transylvanian Basin (Romania): implications for hydrocarbon exploration. Mar. Pet. Geol. 27, 191-214.

Krézsek, C., Lăpădat, A., Mațenco, L., Arnberger, K., Barbu, V., Olaru, R., 2013. Strain partitioning at orogenic contacts during rotation, strike-slip and oblique convergence: Paleogene-Early Miocene evolution of the contact between the South Carpathians and Moesia. Glob. Planet. Chang. 103, 63-81.

Leever, K.A., Matenco, L., Bertotti, G., Cloetingh, S., Drijkoningen, G.G., 2006. Late orogenic vertical movements in the Carpathian Bend Zone - seismic constraints on the transition zone from orogen to foredeep. Basin Res. 18, 521-545.

Leever, K.A., Matenco, L., Garcia-Castellanos, D., Cloetingh, S.A.P.L., 2011. The evolution of the Danube gateway between central and eastern Paratethys (SE Europe): insight from numerical modelling of the causes and effects of connectivity between basins and its expression in the sedimentary record. Tectonophysics 502, 175-195.

Leever, K.A., Matenco, L. Răbăgia, T., Cloetingh, S., Krijgsman, W., Stoica, M. 2010. Messinian sea level fall in the Dacic Basin (Eastern Paratethys): palaeogeographical implications from seismic sequence stratigraphy. Terra Nova 22, 12-17.

Lenkey, L., 1999. Geothermics of the Pannonian Basin and its bearing on the tectonics of basin evolution. Vrije Universiteit Amsterdam, p. 215.

Lericolais, G., Bourget, J., Popescu, I., Jermannaud, P., Mulder, T., Jorry, S., Panin, N., 2013. Late Quaternary deep-sea sedimentation in the western Black Sea: new insights from recent coring and seismic data in the deep basin. Glob. Planet. Chang. 103, 232-247.

Lericolais, G., Bulois, C., Gillet, H., Guichard, F., 2009. High frequency sea level fluctuations recorded in the Black Sea since the LGM. Glob. Planet. Chang. 66, 65-75.

Letouzey, J., Biju-Duval, B., Dorkel, A., Gonnard, R., Krischev, K., Montadert, L., Sungurlu, O., 1977. The Black Sea: a marginal basin: geophysical and geological data. In: BijuDuval, B., Montadert, L. (Eds.), Structural History of the Mediterranean Basins. Editions Technip, Paris, pp. 363-376.

Magyar, I., Fogarasi, A., Vakarcs, G., Buko, L., Tari, G., 2006. In: Golonka, J., Picha, F.J. (Eds.) The Largest Hydrocarbon Field Discovered to Date in Hungary: Algyo. 84, pp. 619-632.

Magyar, I., Geary, D.H., Muller, P., 1999. Paleogeographic evolution of the Late Miocene Lake Pannon in Central Europe. Palaeogeogr. Palaeoclimatol. Palaeoecol. 147, 151-167.

Magyar, I., Radivojević, D., Sztanó, O., Synak, R., Ujszászi, K., Pócsik, M., 2013. Progradation of the paleo-Danube shelf margin across the Pannonian Basin during the Late Miocene and Early Pliocene. Glob. Planet. Chang. 103, 168-173.

Major, C.O., Goldstein, S.L., Ryan, W.B.F., Lericolais, G., Piotrowski, A.M., Hajdas, I., 2006 The co-evolution of Black Sea level and composition through the last deglaciation and its paleoclimatic significance. Quat. Sci. Rev. 25, 2031-2047.

Matenco, L., Andriessen, P., 2013. Quantifying the mass transfer from mountain ranges to deposition in sedimentary basins: source to sink studies in the Danube Basin-Black Sea system. Glob. Planet. Chang. 103, 1-18.

Matenco, L, Bertotti, G, Leever, K, Cloetingh, S., Schmid, S, Tărăpoancă, M , Dinu, C, 2007. Large-scale deformation in a locked collisional boundary: interplay between subsidence and uplift, intraplate stress, and inherited lithospheric structure in the late stage of the SE Carpathians evolution. Tectonics 26, TC4011. http://dx.doi.org/10. 1029/2006TC001951.

Matenco, L., Krézsek, C., Merten, S., Schmid, S., Cloetingh, S., Andriessen, P., 2010. Characteristics of collisional orogens with low topographic build-up: an example from the Carpathians. Terra Nova 22, 155-165.

Matenco, L., Radivojević, D., 2012. On the formation and evolution of the Pannonian Basin: constraints derived from the structure of the junction area between the Carpathians and Dinarides. Tectonics 31, TC6007.

Matenco, L., Schmid, S., 1999. Exhumation of the Danubian nappes system (South Carpathians) during the early Tertiary: inferences from kinematic and paleostress analysis at the Getic/Danubian nappes contact. Tectonophysics 314, 401-422. http://dx.doi. org/10.1029/2012tc003206.

Merten, S., 2011. Thermo-tectonic Evolution of a Convergent Orogen With Lowtopographic build-up: Exhumation and Kinematic Patterns in the Romanian Carpathians Derived From Thermochronology PhD VU University Amsterdam, Faculty of Earth and Life Sciences, Amsterdam, p. 202.

Merten, S., Matenco, L., Foeken, J.P.T., Andriessen, P.A.M., 2011. Toward understanding the post-collisional evolution of an orogen influenced by convergence at adjacent plate margins: Late Cretaceous-Tertiary thermotectonic history of the Apuseni Mountains. Tectonics 30, TC6008. http://dx.doi.org/10.1029/2011tc002887. 
Merten, S., Matenco, L., Foeken, J.P.T., Stuart, F.M., Andriessen, P.A.M., 2010. From nappe stacking to out-of-sequence postcollisional deformations: Cretaceous to Quaternary exhumation history of the SE Carpathians assessed by low-temperature thermochronology. Tectonics 29, TC3013. http://dx.doi.org/10.1029/2009tc002550.

Micu, M., Bălteanu, D., 2013. A deep-seated landslide dam in the Siriu Reservoir (Curvature Carpathians, Romania). Landslides 10, 323-329.

Morley, C.K., 1996. Models for relative motion of crustal blocks within the Carpathian region, based on restorations of the outer Carpathian thrust sheets. Tectonics 15 (4), 885-904.

Munteanu, I., Matenco, L., Dinu, C., Cloetingh, S., 2011. Kinematics of back-arc inversion of the Western Black Sea Basin. Tectonics 30, TC5004. http://dx.doi.org/10.1029/ 2011 tc002865.

Munteanu, I., Matenco, L., Dinu, C., Cloetingh, S., 2012. Effects of large sea-level variations in connected basins: the Dacian-Black Sea system of the Eastern Paratethys. Basin Res. 24, 583-597.

Munteanu, I., Willingshofer, E., Matenco, L., Sokoutis, D. Cloetingh, S., 2014. Far-field contractional polarity changes in models and nature. Earth Planet. Sci. Lett. 395, 101-115.

Munteanu, I., Willingshofer, E., Sokoutis, D., Matenco, L., Dinu, C., Cloetingh, S., 2013. Transfer of deformation in back-arc basins with a laterally variable rheology: constraints from analogue modelling of the Balkanides-Western Black Sea inversion. Tectonophysics 602, 223-236.

Nedea, P.S., Pacu, E., Milea, O.M., 2012. The impact on landscape generated by works of improving the navigation conditions on Danube between Calarasi-Braila. Anal. Ser. Stiint. Econ. T. XVIII, 102-109.

Nicholas, W.A., Chivas, A.R., Murray-Wallace, C.V., Fink, D., 2011. Prompt transgression and gradual salinisation of the Black Sea during the early Holocene constrained by amino acid racemization and radiocarbon dating. Quat. Sci. Rev. 30, 3769-3790.

Nikishin, A.M., Okay, A.I., Tüysüz, O., Demirer, A., Amelin, N., Petrov, E., 2015. The Black Sea basins structure and history: new model based on new deep penetration regional seismic data. Part 1: basins structure and fill. Mar. Pet. Geol. 59, 638-655.

Okay, A.I., Celal Sengor, A.M., Gorur, N., 1994. Kinematic history of the opening of the Black Sea and its effect on the surrounding regions. Geology 22, 267-270.

Popescu, I., Lericolais, G., Panin, N., Normand, A., Dinu, C., Le Drezen, E., 2004. The Danube submarine canyon (Black Sea): morphology and sedimentary processes. Mar. Geol. 206, 249-265.

Popescu, I., Lericolais, G., Panin, N., Wong, H.K., Droz, L., 2001. Late Quaternary channel avulsions on the Danube deep-sea fan, Black Sea. Mar. Geol. 179, 25-37.

Popov, S.V., Shcherba, I.G., Ilyina, L.B., Nevesskaya, L.A., Paramonova, N.P., Khondkarian, S.O., Magyar, I., 2006. Late Miocene to Pliocene palaeogeography of the Paratethys and its relation to the Mediterranean. Palaeogeogr. Palaeoclimatol. Palaeoecol. 238, 91-106.

Pubellier, M., Morley, C.K., 2014. The basins of Sundaland (SE Asia): evolution and boundary conditions. Mar. Pet. Geol. 58, 555-578 (Part B).

Răbăgia, T, Matenco, L Cloetingh, S., 2011. The interplay between eustacy, tectonics and surface processes during the growth of a fault-related structure as derived from sequence stratigraphy: the Govora-Ocnele Mari antiform, South Carpathians. Tectonophysics $502,196-220$

Rădoane, M., Rădoane, N., 2005. Dams, sediment sources and reservoir silting in Romania. Geomorphology 71, 112-125.

Rădoane, M., Rădoane, N., Dumitriu, D., 2003. Geomorphological evolution of longitudinal river profiles in the Carpathians. Geomorphology 50, 293-306.

Rögl, F., 1999. Mediteranean and Paratethys. Facts and hypotheses of an Oligocene to Miocene paleogeography. Geol. Carpath. 50, 339-349.

Romanescu, G., Nistor, I., 2011. The effects of the July 2005 catastrophic inundations in the Siret River's Lower Watershed, Romania. Nat. Hazards 57, 345-368.

Roure, F., Roca, E., Sassi, W., 1993. The Neogene evolution of the outer Carpathian flysch units (Poland, Ukraine and Romania); kinematics of a foreland/fold- and-thrust belt system. Sediment. Geol. 86, 177-201.

Schmid, S., Bernoulli, D., Fügenschuh, B., Matenco, L., Schefer, S., Schuster, R., Tischler, M. Ustaszewski, K., 2008. The Alpine-Carpathian-Dinaridic orogenic system: correlation and evolution of tectonic units. Swiss J. Geosci. 101, 139-183.

Schmid, S.M., Bernoulli, D., Fügenschuh, B., Matenco, L., Schefer, S., Oberhänsli, R., Ustaszewski, K., 2011. Tracing the closure of Neotethys from the Alps to Western Turkey II: similarities and differences between Dinarides, Hellenides and Anatolides-Taurides. Geophys. Res. Abstr. 13 EGU2011-4000.

Seghedi, I., Matenco, L., Downes, H., Mason, P.R.D., Szakács, A., Pécskay, Z., 2011. Tectonic significance of changes in post-subduction Pliocene-Quaternary magmatism in the South East part of the Carpathian-Pannonian Region. Tectonophysics 502, 146-157.

Soulet, G., Ménot, G., Lericolais, G., Bard, E., 2011. A revised calendar age for the last reconnection of the Black Sea to the global ocean. Quat. Sci. Rev. 30, 1019-1026.

Stănică, A., Dan, S., Jimenez, J.A., Ungureanu, G.V., 2011. Dealing with erosion along the Danube Delta coast. The CONSCIENCE experience towards a sustainable coastline management. Ocean Coast. Manag. 54, 898-906.
Stănică, A., Panin, N., 2009. Present evolution and future predictions for the deltaic coastal zone between the Sulina and Sf. Gheorghe Danube river mouths (Romania). Geomorphology 107, 41-46.

Stoica, M., Lazăr, I., Krijgsman, W., Vasiliev, I., Jipa, D., Floroiu, A., 2013. Paleoenvironmental evolution of the East Carpathian foredeep during the late Miocene-early Pliocene (Dacian Basin; Romania). Glob. Planet. Chang. 103, 135-148.

Stojadinovic, U., Matenco, L., Andriessen, P.A.M., Toljić, M., Foeken, J.P.T., 2013. The balance between orogenic building and subsequent extension during the Tertiary evolution of the NE Dinarides: constraints from low-temperature thermochronology. Glob. Planet. Chang. 103, 19-38.

Strechie, C., Andre, F., Jelinowska, A., Tucholka, P., Guichard, F., Lericolais, G., Panin, N., 2002. Magnetic minerals as indicators of major environmental change in Holocene Black Sea sediments: preliminary results. Phys. Chem. Earth Parts A/B/C 27, 1363-1370.

Syvitski, J.P.M., Kettner, A.J., Overeem, I., Hutton, E.W.H., Hannon, M.T., Brakenridge, G.R. Day, J., Vorosmarty, C., Saito, Y., Giosan, L., Nicholls, R.J., 2009. Sinking deltas due to human activities. Nat. Geosci. 2, 681-686.

Tărăpoancă, M., Garcia-Castellanos, D., Bertotti, G., Matenco, L., Cloetingh, S.A.P.L., Dinu, C., 2004. Role of the 3-D distributions of load and lithospheric strength in orogenic arcs: polystage subsidence in the Carpathians foredeep. Earth Planet. Sci. Lett. 221, 163-180.

Tari, G., Davies, J., Dellmour, R., Larratt, E., Novotny, B., Kozhuharov, E., 2009. Play types and hydrocarbon potential of the deepwater Black Sea, NE Bulgaria. Lead. Edge 28, 1076-1081.

Tari, G., Horváth, F., Rumpler, J., 1992. Styles of extension in the Pannonian basin. Tectonophysics 208, 203-219.

ter Borgh M. Connections between sedimentary basins during continental collision: how tectonic, surface and sedimentary processes shaped the Paratethys. Utrecht Studies in Earth Sciences 45. PhD. Utrecht University, (PhD Thesis), Utrecht, 2013, pp. 212.

ter Borgh, M., Radivojević, D., Matenco, L., 2015. Constraining forcing factors and relative sea-level fluctuations in semi-enclosed basins: the Late Neogene demise of Lake Pannon. Basin Res. (in press: doi: 10.1111/bre.12094.).

ter Borgh, M., Stoica, M., Donselaar, M.E., Matenco, L., Krijgsman, W., 2014. Miocene connectivity between the Central and Eastern Paratethys: constraints from the western Dacian Basin. Palaeogeogr. Palaeoclimatol. Palaeoecol. 412, 45-67.

ter Borgh, M. Vasiliev, I., Stoica, M., Knežević, S., Matenco, L., Krijgsman, W., Rundić, L. Cloetingh, S., 2013. The isolation of the Pannonian basin (Central Paratethys): new constraints from magnetostratigraphy and biostratigraphy. Glob. Planet. Chang. 103, 99-118.

Tiliță, M., Matenco, L., Dinu, C., Ionescu, L., Cloetingh, S., 2013. Understanding the kinematic evolution and genesis of a back-arc continental "sag" basin: the Neogene evolution of the Transylvanian Basin. Tectonophysics 602, 237-258.

Timar, G., Sumegi, P., Horvath, F., 2005. Late Quaternary dynamics of the Tisza River: evidence of climatic and tectonic controls. Tectonophysics 410, 97-110.

Toljić, M., Matenco, L., Ducea, M.N., Stojadinović, U., Milivojević, J., Đerić, N., 2013. The evolution of a key segment in the Europe-Adria collision: the Fruška Gora of northern Serbia. Glob. Planet. Chang. 103, 39-62.

Ustaszewski, K., Kounov, A., Schmid, S.M., Schaltegger, U., Krenn, E., Frank, W., Fügenschuh, B., 2010. Evolution of the Adria-Europe plate boundary in the northern Dinarides: from continent-continent collision to back-arc extension. Tectonics 29 , TC6017. http://dx.doi.org/10.1029/2010tc002668.

Ustaszewski, K., Schmid, S., Fügenschuh, B., Tischler, M., Kissling, E., Spakman, W., 2008. A map-view restoration of the Alpine-Carpathian-Dinaridic system for the Early Miocene. Swiss J. Geosci. 101, 273-294.

Uyeda, S., Kanamori, H., 1979. Back-arc opening and the mode of subduction. J. Geophys. Res. 84, 1049-1061.

van der Hoeven, A.G.A., Mocanu, V., Spakman, W., Nutto, M. Nuckelt, A., Matenco, L. Munteanu, L., Marcu, C., Ambrosius, B.A.C., 2005. Observation of present-day tectonic motions in the Southeastern Carpathians: results of the ISES/CRC-461 GPS measurements. Earth Planet. Sci. Lett. 239, 177-184.

van der Meer, M.T.J., Sangiorgi, F., Baas, M., Brinkhuis, H., Sinninghe Damsté, J.S., Schouten, S., 2008. Molecular isotopic and dinoflagellate evidence for Late Holocene freshening of the Black Sea. Earth Planet. Sci. Lett. 267, 426-434.

Vergés, J., Fernàndez, M., 2012. Tethys-Atlantic interaction along the Iberia-Africa plate boundary: the Betic-Rif orogenic system. Tectonophysics 579, 144-172.

von Quadt, A., Moritz, R., Peytcheva, I., Heinrich, C.A., 2005. 3: Geochronology and geodynamics of Late Cretaceous magmatism and $\mathrm{Cu}-\mathrm{Au}$ mineraslization in the Panagyurishte region of the Apuseni-Banat-Timok-Srednogorie belt, Bulgaria. Ore Geol. Rev. 27, 95-126.

Wortel, M.J.R., Spakman, W., 2000. Subduction and Slab Detachment in the Mediteranean-Carpathian Region. Science 290, 1910-1917. 